\title{
The West's Teeth: IMF Conditionality During the Cold War
}

\author{
Ariel Akerman* Leonardo Weller ${ }^{\dagger} \quad$ João Paulo Pessoa ${ }^{\ddagger}$
}

October 7, 2020

\begin{abstract}
Did the International Monetary Fund (IMF) play a role in the United States and its Western allies efforts to contain the advance of communism during the Cold War? To answer this question, we construct a new database containing the number of conditions applied to over 500 IMF loans since 1970 and analyze how the distance from a borrowing country to its closet communist neighbor affected the IMF conditionality. We show that the Fund imposed fewer conditions on loans to countries geographically closer to the communist bloc. Results are stronger when neighboring communist countries were not part of the Warsaw Pact. This pattern persisted during the 1990s, when the Fund helped former communist countries in their transition to market economies. However, we find no strong evidence of such discretionary treatment by the IMF after 2001, when the containment of communism had ceased to be the West's top priority.
\end{abstract}

Keywords: International Monetary Fund, Conditionality, Cold War.

JEL: F34, F53, H63, O19

*Boston University. E-mail: ariaker@bu.edu

${ }^{\dagger}$ São Paulo School of Economics - FGV. E-mail: leonardo.weller@fgv.br

${ }^{\ddagger}$ São Paulo School of Economics - FGV and Centre for Economic performance. E-mail: joao.pessoa@fgv.br. Corresponding author. 


\section{Introduction}

In 1975, the Popular Liberation Movement (MPLA), a communist military group backed by the Soviet Union, gained ground in its war against the anti-communist National Union for the Total Independence of Angola (UNITA) over the control of Angola. MPLA's successive victories threatened the stability of the right-wing dictatorship of Mobutu Sese Seko in neighboring Zaire (today, the Democratic Republic of Congo), an impoverished country that faced a balance of payment crisis. Without financial resources to arm its military, Mobutu was dangerously exposed to the spread of communism coming from the other side of the border. The US Secretary of State Henry Kissinger called for a conference on the Zaire issue, during which Sheldon Vance, the ambassador in Kinshasa, declared that "[w]e have to help them [Mobutu's administration] via the International Monetary Fund (IMF) to get over his short-term cash flow problem. Our people think this is reasonable." "Shortly after that, Kissinger paid a visit to Zaire to convince Mobutu to accept the IMF Stand-By Arrangement that was subject to no binding conditions. $^{2}$

In this article, we investigate if the United States and its Western allies (hereafter the West) consistently used the IMF as an instrument in their global fight against communism during the Cold War. We do so by exploring variations in the conditions binding to IMF loans. Officially, the IMF designs conditions to strengthen the balance of payment, promote development, and support orthodox macroeconomic policies in borrowing countries, therefore reducing their future need of further loans (Polak, 1991). However, many authors have discussed the way the Fund imposes conditions on borrowers. ${ }^{3}$ Crucially for this article, Dreher and Jensen (2007) point out that the number of conditions significantly varies across countries. The authors show evidence that the IMF imposes fewer conditions on governments that vote together with the West in the United Nations General Assembly (UNGA). In line with that claim, Polak (1991, 32) reports that senior IMF staff admit that "[t]he proprieties of the [International Monetary] Fund contain an unwritten rule that political arguments should be dressed up in economic garb whenever possible."

Previous studies on the IMF conditionality, however, focus on a relatively short period, from the mid-1990s to the 2000s, most likely because of the lack of data. We address this gap by studying the conditions since 1970, which enables us to assess the impact of the Cold War in the way the Fund imposed conditions on borrowing governments. This periodization is also relevant because the IMF expanded its role as an international lender of last resort during the 1970s oil shocks and the debt crises of the 1980s. That all happened in the context of the global

\footnotetext{
${ }^{1}$ Foreign Relations of the United States, 1969-1976, Volume XXVIII, Southern Africa, eds. Myra F. Burton (Washington: Government Printing Office, 2011), Document 112.

${ }^{2}$ Foreign Relations of the United States, 1969-1976, Volume E-6, Documents on Africa, 1973-1976, eds. Peter Samson and Laurie Van Hook (Washington: Government Printing Office, 2006), Documents 278-300.

${ }^{3}$ For example, Collier et al. (1997) and Dreher (2009) assert that the IMF conditions are too harsh, Kentikelenis et al. (2016) argue that they reflect the fuss that involves the Fund's missions, and Auvinen (1996) conclude that the IMF is at the root of social unrest in developing countries.
} 
fight against communism.

To assess how the IMF imposed conditions on borrowers during the Cold War, we build a new database from the letters of intent and agreement texts of approximately 500 loans from 1970 to 1986, all of which are in the Fund's archives, but, to our knowledge, have not been systematically analyzed before. We codify the available information on these letters in line with the work by Kentikelenis et al. (2016), which quantifies the number of conditions per loans for the period 1986-2014. In other words, we extend the database originally assembled by Kentikelenis et al. (2016) back to 1970. We then regress the number of conditions applied to each loan on the distance from the capital of every borrowing country to the capital of the closest communist and Soviet-allied country, controlling for macroeconomic and political variables. ${ }^{4}$ We restrict our analysis to the conditions included in the Stand-By Arrangements because it is the oldest, most frequent and consistent in the Fund's portfolio (Gould, 2006, 216-218).

We show that the Stand-By Arrangements sealed with governments in countries that were closer to the communist bloc contained, on average, fewer conditions. In 1975, for example, we estimate that the threat of communism generated by Cuba led some neighboring countries in Central America to obtain IMF loans with approximately one third of the number of conditions that they would have obtained if Cuba was under a non-communist regime.

To better understand the geographical and political components behind these effects, we break the communist bloc into two groups: (a) the Warsaw Pact and Comecon members (most of Eastern European, Cuba, Mongolia, and Vietnam) (b) the remaining countries, most of which were in Africa and Asia. The results are stronger and more robust for those countries whose nearest communist neighbor was not in either the Warsaw Pact or the Comecon, such as Zaire in relation to Angola in 1975, as explained in the example above, and countries in Central America in relation to Cuba. This suggests that the Cold War was especially "hot" away from the relatively well-established European Iron Curtain. International relations were more volatile and the spread of communism more dangerous in Africa and Asia. Hence, this article's main conclusion is that the IMF acted accordingly to the West's geopolitical goals, favoring borrowers that were more vulnerable to the global spread of communism across the world and faraway from the Warsaw Pact.

We conduct our exercise for 1970-1991 and 1970-2001. Overall, the results hold for both periods, but they are more robust for the latter. This reflects the fact that the inclusion of former communist countries in the international financial system was a top priority of the West until the 9/11 attacks, after which the war on terrorism became more important than Cold Warrelated issues. We run a placebo test for the post-2001 period, finding no significant effect of distance to communist countries on IMF conditionality over that period. We also perform a robustness check with an alternative measures of proximity to communism: the border shared with neighboring Communist countries. The results generally corroborate our conclusion that

\footnotetext{
${ }^{4}$ This distance-based methodology is in line with the work by Sant'Anna and Weller (2020) on the Cold War, according to which communism was a greater threat to countries that were closer to the communist bloc.
} 
the Cold War influenced how the IMF operated.

This article proceeds as follows: Section 2 offers a discussion of the literature on IMF conditionality, Section 3 presents the data, Section 4 exposes the econometric exercises and analyses its results, and Section 5 concludes the article.

\section{The political economy of the IMF and geopolitics}

Officially, the IMF pursues strictly economical goals, such as the promotion of international financial stability, trade and monetary cooperation. The process of lending follows previously established protocols designed to preserve a technical decision-making process: managers negotiate lending contracts, which, before resulting in credit transfers, need the approval of the Executive Board and are formalized in Letters of Intent that contain information such as credit amount, terms and conditions (International Monetary Fund, 2011). Nevertheless, there is plenty of space within the IMF for its largest shareholders to influence how much and under what conditions should countries borrow. The Fund's member-states vote to appoint managers and to decide how the Executive Board should act. Votes are proportional to the Special Drawing Rights, the deposits governments own in the IMF. The deposit values - and consequentially of votes - vary considerably across countries and are concentrated in a few members.

The United States has always owned the largest share of votes in the IMF. Although the US share has shrunk considerably since the 1960s, as shown in Figure 1, it still responded to 1/6 of the total. Likewise, the G7's share fell by 22 per cent in that period but still accounts for almost half (See Appendix). Quotas usually change due to the incorporation of new members and to gradual and periodical revisions. Nevertheless, the fall in shares was not sufficient to undermine the West and the United States' influence on the IMF.

The IMF has as a wide discretionary margin, and hence may be under especially political pressure, particularly when imposing and enforcing policy conditions on borrowers. Conditions include politically sensitive topics such as privatizations, the implementation of orthodox monetary policy, the end of subsidies, and the achievement of fiscal targets.

The IMF may suspend credit lines to borrowers that fail to fulfil conditions without the need for approval by the Executive Board (International Monetary Fund, 2002). According to Stone (2004), political pressures may affect the rate of suspension, which creates a moral hazard problem that explains why the rate of compliance is rather low, under 60 per cent (Polak, 1991; Ivanova et al., 2003).

There is a consensus in the literature that the West - and the United States in particular - does pressure the IMF to benefit politically-aligned borrowing countries. In a historical-qualitative study, McKeown (2009) describes how the US government built its political influence over the IMF in the 1960s and 1970s. Along the same lines, Momani (2004) presents documentation according to which the United States shaped the relationship between the Fund and Egypt, a key Arab ally, to support the Mubarak regime in the 1980s. 


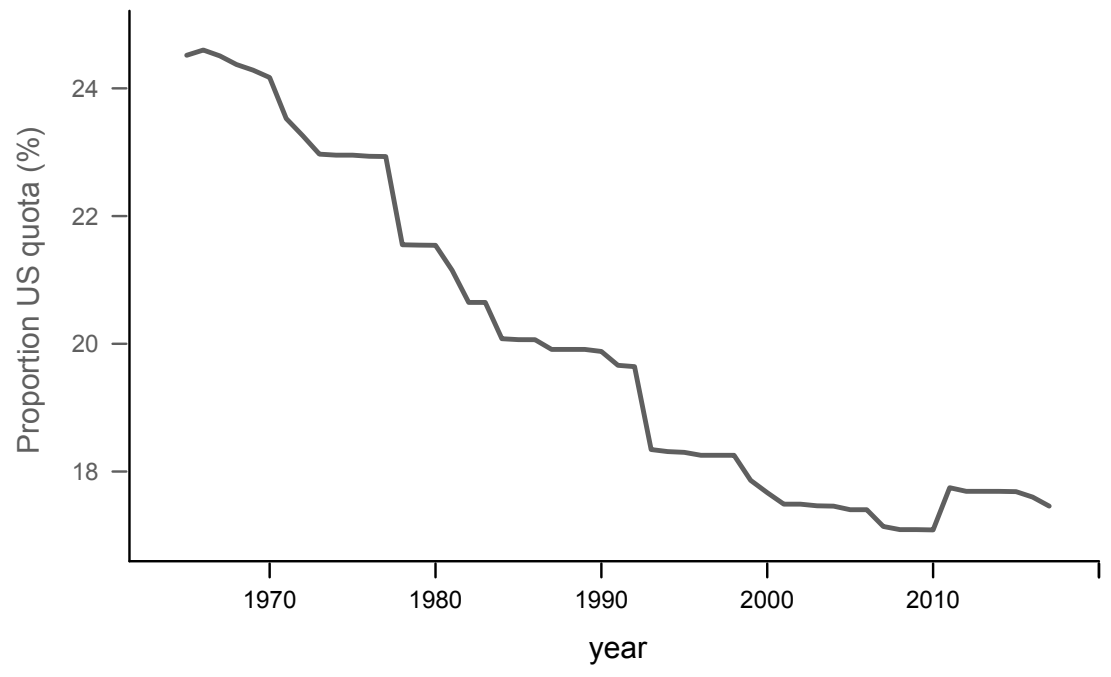

Figure 1: Evolution of total IMF quota and US relative position

Notes: Self-elaboration using hand collected data from IMF Annual Reports.

A broad literature investigates whether governments that are diplomatically aligned to the largest IMF voters-- that is, aligned to the West -- have reached better deals than non-aligned borrowers. In doing so, the literature addresses two methodological questions that are relevant for this article: (1) how one should measure the degree to which the IMF can be harsh or soft on borrowing countries, and (2) how should one define countries as close or distant to the West.

Thacker (1999), Barro and Lee (2005), Andersen et al. (2006) answer the first question by identifying the determinants of the probability of a given country to reach an agreement with the IMF. Oatley and Yackee (2004) and Reynaud and Vauday (2009) assess why some agreements include more conditions than others. These scholars ground their arguments on ordinary least squares regressions of the IMF lending variables against politically-related variables, usually controlling for the economic conditions of the borrower. Our article resorts to this general approach to measure how harsh the IMF has been when granting loans, with the key difference that we are able to focus on the US geopolitical interests during the cold war period, something not previously addressed in the literature due to data limitations.

Several authors provide a number of different approaches to explain the second question. Barro and Lee (2005) qualify countries as close or distant to the West, depending on how many nationals work for the IMF. Oatley and Yackee (2004) classify countries as close to the United States depending on how much they owe to the US government. Reynaud and Vauday (2009) stress the role of geopolitics in defining countries as relevant or irrelevant, while Dreher (2004); Dreher et al. (2009b, 2015) asserts that countries are close if they are active in the World Bank or participate in the UN Security Council.

Thacker (1999) relates both questions in his seminal work on the geopolitical determinants of IMF lending. He finds a positive correlation between the probability of a given government 
reaching a Stand-By Arrangement and its alignment with the United States in the Security Council between 1985 and 1995. Dreher and Jensen (2007) present a similar result by extending the alliance to the G7 as a whole, while Copelovitch (2010) reaches the same conclusion for a group of countries he refers to as the G5: The United States, United Kingdom, France, Germany, and Japan. These conclusions are in line with the "politics-oriented IMF" hypothesis proposed by Stone (2008), according to whom the IMF works as an informal US aid agency, compensating for the rigidity to which the US government is subject due to Congress' prerogatives on foreign policy. ${ }^{5}$ These authors use the simple sum of conditions attached to every loan as a proxy of IMF's harshness and conclude that the Fund imposes fewer conditions to West-aligned governments. The only exception in the literature is Stone (2008), who counts the number of policy areas the conditions touch instead of treating all conditions as equal. Guimaraes and Ladeira (2018) explore this debate in their recent article, which shows that the sum of IMF conditions is indeed negatively correlated with the alignment with the G7 in the UN. Still, they find no result when restricting the conditions to fiscal policy, perhaps the most sensitive policy area to borrowing governments.

Other papers are closely related to our work as they explore the political pressures of World Bank projects. Moon et al. (2014) show that the IMF fails to increase FDI in US-allies, since investors perceives the missions to these countries as politically rather than technically driven. Kersting and Kilby (2016), instead, find evidence that countries that are politically aligned with the World Bank-IMF's major shareholders are more likely to receive an improved risk rating (implied by the application of the Debt Sustainability Framework). Lang and Presbitero (2018) show that World Bank's investment project loans disburse faster when borrowing countries are aligned with the US in the United Nations. They also find that upcoming (competitive) elections in the borrowing countries augments the speed of disbursement if the government is geopolitically aligned with the US, but the opposite happens if the government is not. Dreher et al. (2009a), moreover, identify that countries that are temporary members of the United Nations Security Council face higher probability of receiving a World Bank project. Kilby (2013) shows that a higher alignment to the US in the United Nations General Assembly voting is associated to lighter conditionality enforcement by the World Bank.

As we provide evidence on the IMF's susceptibility to geopolitical pressures, we further relate to a broader literature concerning the political economy of US international trade. Berger et al. (2013) show the connection between CIA interventions in foreign countries during the Cold War and the increase in exports from the United States to those countries. This paper also has significance for the investigations on the geopolitical exploitation of international aid. Alesina and Dollar (2000) identify that donors have political preferences when choosing the receivers. Fleck and Kilby (2010) show how the aid of USA to poor and developing countries decreased after the fall of the Berlin wall and how it was reoriented on the dawning of the War

\footnotetext{
${ }^{5}$ In a related paper, Dreher et al. (2018) show that the US "hid" some foreign policy interventions from domestic audiences by granting loans via the IMF instead of providing direct bilateral aid.
} 
on Terror. This agrees with the work of Lis (2014), that identifies that countries that suffer more terrorism incidents receive more international aid.

Our article contributes to the literature by exploring new historical data from primary sources. Instead of focusing on methodological issues, we follow the bulk of the literature and measure transparently the degree to which the IMF has been soft or hash by counting the number of conditions attached to every loan. We do so along the lines of the classification proposed by Kentikelenis et al. (2016) in their work on conditionality since 1986.

We also contribute to the literature on the IMF and the Cold War, which does not reach a single conclusion on whether the Fund played a role in containing communism. Stiles (1990) and Westad (2005, 207-249) present the IMF as a tool in US foreign policy in the case of Zaire. In contrast, Kedar $(2015,2017)$ shows that socialist Chile under Allende collaborated with the IMF in spite of the opposition from the US government. Thacker (1999) and Oatley and Yackee (2004) do not find statistically significant results that support the hypotheses that the IMF traded loans for votes aligned with the United States in the UN before 1990. Our analysis shows a different conclusion in an exercise that is arguably more complete, for it relates the IMF directly to the Cold War, controlling for voting in the UN.

\section{Data and Empirical Strategy}

We collected more than 300 SBA letters of intent and memoranda of economic policy from the IMF Archives, dating from 1970 to 1985 . Then, following the methodology in Kentikelenis et al. (2016) for the period 1986-2014, we measure the number of conditions binding to every agreement as the sum of all the conditions described in its text multiplied by their respective incidence. ${ }^{6}$ Our dependent variable is the conjunction of the number of conditions calculated from our own research for the period 1970-1985 and similar work by Kentikelenis et al. (2016) for the three following decades. Our period of analysis starts in 1970 because the IMF carried out a major revision of lending conditionality in the late 1960s (Gould, 2003), which makes our data comparable throughout the following decades.

Our IMF conditionality database is, as far as we are aware, the most comprehensive for the 1970s and 1980s. IMF's MONA reports data on lending back to 1992. Gould (2003, 2006) does cover the previous period but is restricted to samples of loans and specific dimensions of conditionalities. Figure 2 plots the distribution of the number of conditions we identified along the period under study.

Figure 3 presents a map with the average number of conditions, by country, applied to SBAs from 1970 to 2001 . The number of conditions per loan vary significantly and are considerably spread out across the world, with substantial heterogeneity within continents. We can also see that several countries did not receive any loans during the period, and hence, are out of our

\footnotetext{
${ }^{6}$ In the appendix, we also discuss similar results using other ways to sum conditions. Our main conclusions are robust to alternative specifications of the dependent variable.
} 


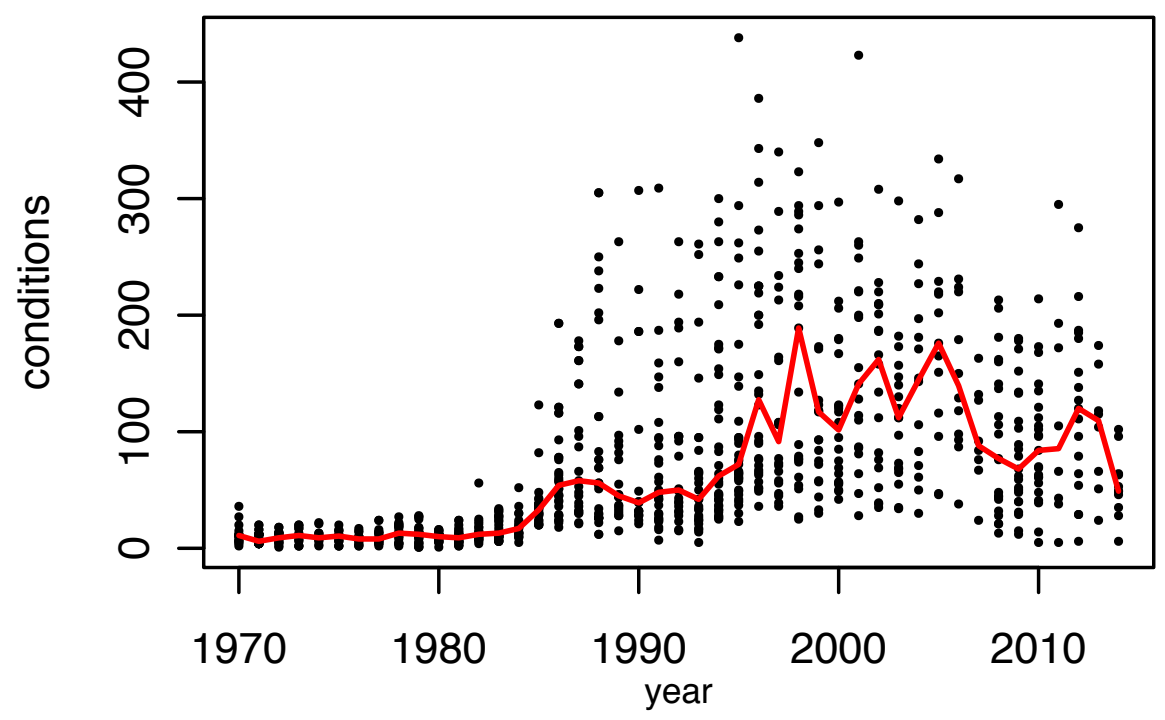

Figure 2: Conditions in IMF arrangements, 1970-2014

Notes: Self-elaboration using a set merging Kentikelenis et al. (2016) and hand-collected data. The red line indicates the median by year.

sample.

The IMF launched approximately 900 loans from 1970 to 2014, of which about 500 were Stand-By Arrangement (SBA). We only take SBAs into account in our analysis. SBAs have typically a one year-long-maturity and are attached to fewer conditions, as shown in Figure 4, which makes them more consistent than other facilities. ${ }^{7}$ Hence, by restricting our analysis to SBAs, we mitigate the concern of capturing variations in the number of conditions caused by the heterogeneous patterns across lending facilities rather than differences in the relations between the IMF and every borrowing country.

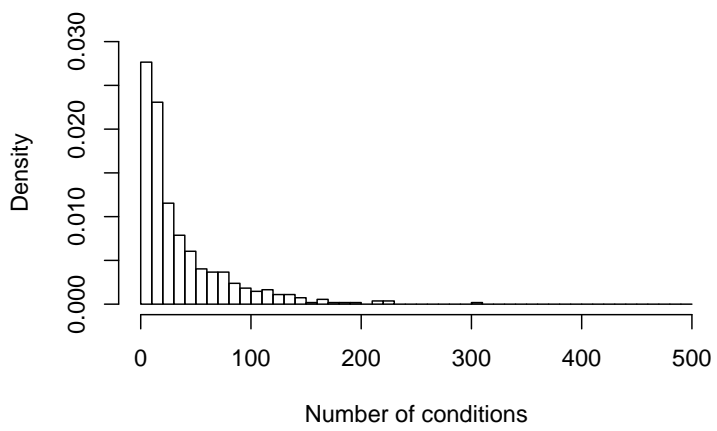

(a) SBA arrangements

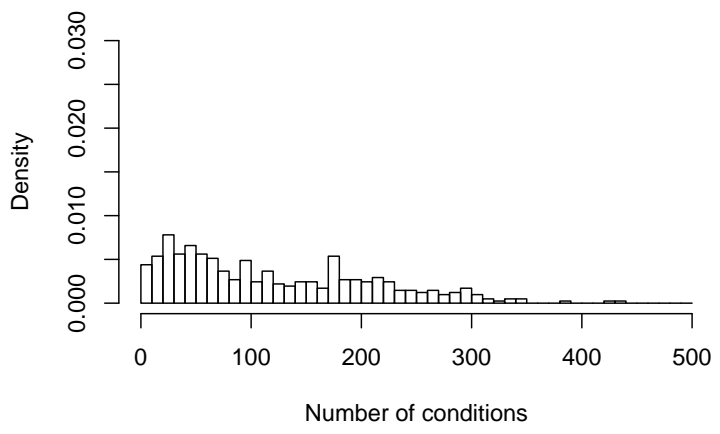

(b) Non-SBA arrangements

Figure 4: Distributions of conditions by SBA and non-SBA arrangements

Notes: self-elaboration using a set merging Kentikelenis et al. (2016) and data we collected from IMF Archive documents. We used the criteria of Kentikelenis et al. (2016) to map conditionality.

Our main variable of interest is the distance from a borrower's capital to the capital of the

${ }^{7}$ SeeGould (2006, 37-72). 


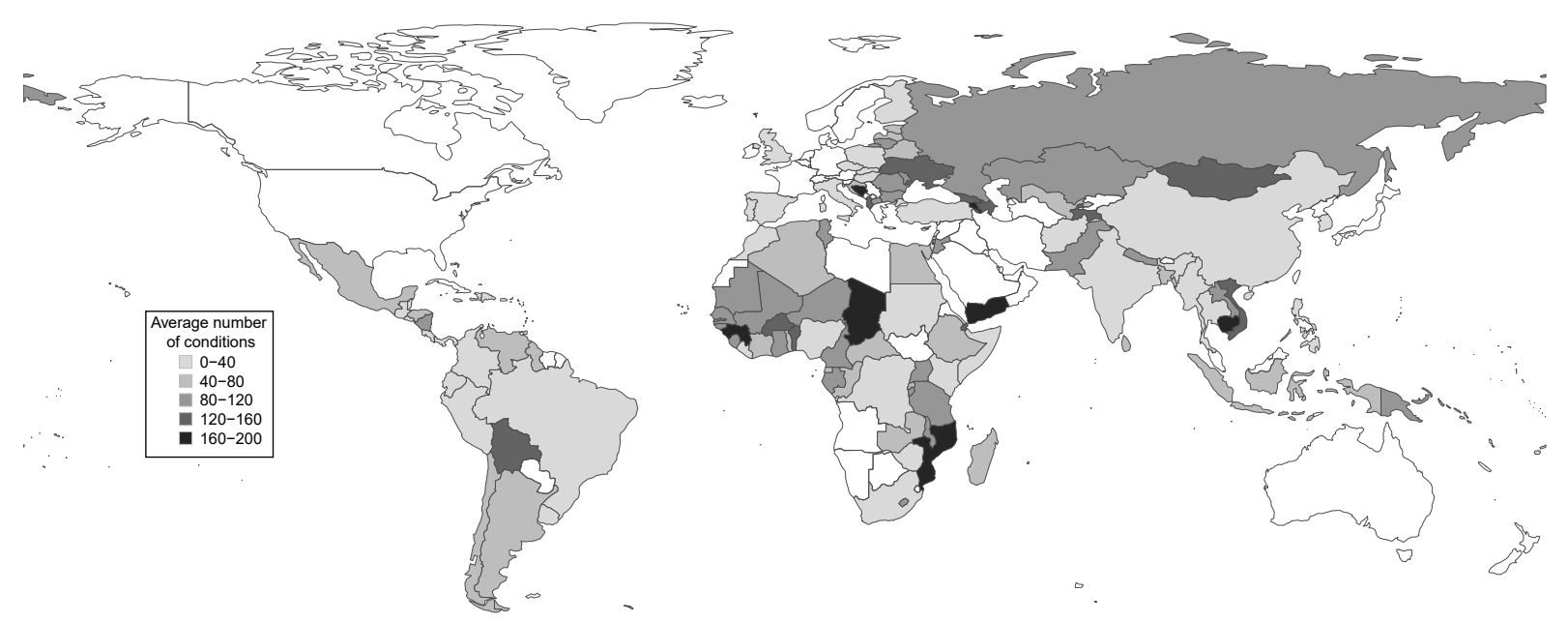

Figure 3: Average number of conditions in IMF SBA agreements by country, 1970-2001. Data from the authors and Kentikelenis et al. (2016).

closest communist country. ${ }^{8}$ This approach rests on the assumption that the distance between countries is proportional to the probability of conflict, ideology spreading, and diplomatic representation. ${ }^{9}$ For the particular case of the Cold War, we assume that countries that were close to the communist bloc were more susceptible to the spread of communism. ${ }^{10}$ In other words, the closer a country is to a West's enemies, the more "strategic" it would be to Western leaders. Along these lines, the Department of State of the United States declared that:

[g]eographical proximity to the Soviet Union was considered to be the prime source of infection and as such neighboring states would not only have to be vigilant but also prepared to fight the spread of communism. (Dodds, 2007, 209)

This variable may contain possible biases, for geographical distance does not take topography, rivers and oceans into account. To mitigate this potential flaw, in the robustness checks section we test for an alternative variable that takes borders and population into account. In an additional exercise, we break our variable of interest into the distance to: (1) members of the Warsaw Pact or the Council for Mutual Economic Assistance, which included the USSR, Mongolia, Cuba, Vietnam, and Eastern Europe apart from Yugoslavia and Albania; (2) communist countries there were not part of either the Warsaw Pact or the Comecon. We call these variables Distance to WPC and Distance to non-WPC, respectively. This distinction is relevant because Warsaw Pact members were more under the influence of the USSR than the other communist countries, on which the West arguably imposed greater pressure in its global fight against communism (Westad, 2005; Gaddis, 2006).

\footnotetext{
${ }^{8}$ We use the database in Weidmann et al. (2010) for distances between capitals and the classification of communist countries in Haywood (2011), Westad (2005), and Kinder and Hilgemann (2003).

${ }^{9}$ This assumption is recurrent in the international relations literature. See Oneal and Russett (1999), Neumayer (2008), and Head and Mayer (2014).

${ }^{10}$ See Sant'Anna and Weller (2020) for similar assumptions.
} 
Our basic OLS-estimated model, for each arrangement $\mathrm{i}$ and year $\mathrm{t}$, is:

$\log$ conditions $_{i}=\beta_{0}+$ DistanceVariable $_{i} \beta_{1}+$ VotesAtUNGA $_{i} \beta_{2}$

$$
+ \text { PoliticalControls }_{i} \beta_{3}+\text { EconomicControls }_{i} \beta_{4}+\text { Error }_{i} \text {. }
$$

We control for three country-level variables that capture the relationship between a given country and the West: the average of dyadic votes in accordance to the votes of the United States in the UN General Assembly (UNGA); ${ }^{11}$ a dummy that indicates whether the country was a temporary member in the UN Security Counvil; the proportional quota each member has in the IMF; and the proportion of imports from and exports to the United States vis-à-vis total imports and exports, ${ }^{12}$ respectively. Finally, we control for GDP per capita (in 2010 US dollars) and for other macroeconomic variables that capture whether countries were likely to face payment crises: exchange rate variation and CPI from the IMF International Financial Statistics database, GDP growth and the rate of growth of broad money from the World Bank database. We do not use other Balance of Payment variables such as foreign exchange reserves and foreign debt due to the lack of data during the Cold War, when most of Africa and parts of Asia were still forming new independent nation-states. ${ }^{13}$

We consider different specifications with distinct time-level controls to account for potential changes in IMF governance and, crucially, in the US foreign policy along the period of analysis. ${ }^{14}$ Firstly, we include a post-1991 dummy to account for the end of the USSR. Secondly, a dummy variable for years in which Republicans were in the White House captures whether party-politics shaped the way US administrations handled the IMF. Controlling for republican administrations is relevant because the "Cold War Consensus" collapsed in the 1970s, with the Republican Party pushing for aggressive anti-communist military programs while the Democrats adopted a new pacifist agenda - the contrast between the hawkish Reagan and dovish Carter administrations is telling Fordham (2007). It may be the case that, besides military budget, such partisan division also affected the relationship with the IMF. We also consider more stringent specification with year or country fixed effects.

\section{Results}

In the first round of regressions, we consider our model for the period 1970-2001, which takes into account the period of the Cold War per se as well as the decade between the end of the

\footnotetext{
${ }^{11}$ See of Steinwand and Stone (2008) for the source and Strezhnev and Voeten (2013) for a discussion.

${ }^{12} \mathrm{We}$ have hand-collected the quota information from the IMF Annual Reports. Our international trade data is from UN-Comtrade.

${ }^{13}$ In our appendix, however, we include an extension of our main exercises in which we control for the ration between imports and reserves.

${ }^{14}$ For instance, Reagan's arm race followed Carter notoriously pacifist administration. See Westad (2005, 331$363)$.
} 
USSR and the 9/11 attack. The decade between 1991 and 2001 is relevant because issues related to the Cold War, such as the transition of communist into market economies, still guided the West's foreign policy. ${ }^{15}$ Table 1 shows that the coefficient of the variable of interest, Distance to Communist, is significant and positive, meaning that the number of conditions imposed on loans decreased with borrower's distance to a communist country. This result suggests that the IMF requirements were softer for countries that were more exposed to the global spread of communism, which implies that the Fund was a West's tool in the Cold War. ${ }^{16}$ The coefficient increases with the introduction of the Republican dummy, suggesting that party-politics did play a role in the way the United States managed the IMF as a geopolitical tool. However, the dummy's coefficient is negative, which means that, overall, the IMF imposed less conditionality when Republicans were in the White House.

The magnitude of the coefficient is noteworthy. For instance, The IMF imposed 15 conditions when lending to Panamá in 1975, which is very close to the predicted number in our model: 14.7. After Cuba, whose capital Havana was only 1,500 Km apart from Panama City, the second closest communist country is Benin, whose capital city was 9,100 Km away. In a counterfactual scenario without Cuba, the predicted number of conditions for Panama in 1975 would rise to approximately 43 .

\footnotetext{
${ }^{15}$ See Westad $(2005,346-407)$ and Fleck and Kilby (2010) for the transition from communism to capitalism in the 1990s.

${ }^{16}$ In Appendix Table D.1, we consider a specification without our main variable of interest, i.e., the regression includes only the UNGA variable and controls. The coefficients of the UNGA variable are negative, significant and quantitatively similar to the ones in our main exercise in Table 1. Moreover, the results show that previous findings in the literature (Dreher and Jensen, 2007) are robust to our extended database.
} 
Dependent variable: $\log$ (Number of conditions)

(1)

\begin{tabular}{|c|c|c|c|c|}
\hline \multirow[t]{2}{*}{ Distance to Communist } & $0.144^{* * *}$ & $0.046^{* *}$ & $0.122^{* * *}$ & $0.050^{* *}$ \\
\hline & $(0.027)$ & $(0.022)$ & $(0.025)$ & $(0.022)$ \\
\hline \multirow[t]{2}{*}{ Alignment to US at UNGA } & $-2.634^{* * *}$ & $-2.012^{* * *}$ & $-2.767^{* * *}$ & $-2.111^{* * *}$ \\
\hline & $(0.252)$ & $(0.247)$ & $(0.247)$ & $(0.254)$ \\
\hline \multirow[t]{2}{*}{ Year $>1991$} & & $1.066^{* * *}$ & & $0.958^{* * *}$ \\
\hline & & $(0.109)$ & & $(0.131)$ \\
\hline \multirow[t]{2}{*}{ Republican dummy } & & & $-0.536^{* * *}$ & -0.146 \\
\hline & & & $(0.107)$ & $(0.111)$ \\
\hline Other controls & Yes & Yes & Yes & Yes \\
\hline Period & $1970-2001$ & $1970-2001$ & $1970-2001$ & 1970-2001 \\
\hline$N$ & 207 & 207 & 207 & 207 \\
\hline Adjusted $\mathrm{R}^{2}$ & 0.392 & 0.541 & 0.459 & 0.542 \\
\hline
\end{tabular}

Table 1: Determinants of number of conditions (log)

Notes: ${ }^{* * *}$ and ${ }^{* * *}$ represent significance at 10,5 and 1 percent levels, respectively. White robust errors in brackets. Distances... measured in thousands of kilometres. Alignment to US is the proportion of votes at UNGA that were aligned to American votes. Other controls: Exchange rate variation of local currency compared to US dollars, consumer prices variation, GDP growth, broad money growth, GDP per capita measured in thousands of 2010 US dollars, percentage of country's quota in total IMF quotas, proportions of imports from US, exports to US, temporary membership of the United Nations Security Council and a constant term. Column 1 includes no time dummies; column 2 includes a dummy for post-1991 observations; column 3 includes a dummy if the contemporaneous US presidential mandate is Republican; column 4 includes both Republican and post-1991 dummies. We consider only SBA.

Table 2 shows the results with two separate variables of interest: the distance to the closest Warsaw Pact or Comecon member capital, and the distance to the closest capital of a communist country that did not belong to these groups. Even though both the Warsaw Pact and Comecon disappeared in 1991, we maintain the classification of former members in the analysis carried out for the 1990s. Results suggest that the Fund did not deal with the threat to communism the same way everywhere, for it imposed fewer conditions to borrowers that were close to communist countries that were not members of the Warsaw Pact, most of which were in Asia and Africa, away from the European Iron Curtain. This is consistent with the fact that these were the most geopolitical volatile parts of the world, where the Cold War was more violent. The results are in line with Westad $(2005,396)$, according to whom "the most important aspects of the Cold War were neither military nor strategic, nor Europe-centered, but connected to political and social development in the Third World". 
Dependent variable: $\log ($ Number of conditions)

(1)

\begin{tabular}{lcccc}
\hline Distance to Communist non-WPC $\ddagger$ & -0.004 & $0.061^{* * *}$ & $0.045^{* *}$ & $0.070^{* * *}$ \\
& $(0.018)$ & $(0.016)$ & $(0.020)$ & $(0.017)$ \\
Distance to Communist WPC $\ddagger$ & $-0.089^{* * *}$ & -0.030 & $-0.068^{* *}$ & -0.029 \\
& $(0.033)$ & $(0.024)$ & $(0.029)$ & $(0.024)$ \\
Alignment to US at UNGA & $-2.450^{* * *}$ & $-2.102^{* * *}$ & $-2.859^{* * *}$ & $-2.269^{* * *}$ \\
& $(0.268)$ & $(0.253)$ & $(0.283)$ & $(0.272)$ \\
\hline Year $>1991$ & & $1.284^{* * *}$ & & $1.155^{* * *}$ \\
& & $(0.111)$ & & $(0.121)$ \\
Republican dummy & & & $-0.689^{* * *}$ & $-0.222^{* *}$ \\
& & & $(0.127)$ & $(0.112)$ \\
\hline Other controls & Yes & Yes & Yes & Yes \\
Period & $1970-2001$ & $1970-2001$ & $1970-2001$ & $1970-2001$ \\
$N$ & 207 & 207 & 207 & 207 \\
Adjusted $\mathrm{R}^{2}$ & 0.318 & 0.558 & 0.415 & 0.564 \\
\hline \hline
\end{tabular}

Table 2: Determinants of number of conditions (log): Warsaw Pact and Comecon

Notes: ${ }^{*}, * *$ and ${ }^{* * *}$ represent significance at 10,5 and 1 percent levels, respectively. $\ddagger$ indicates fixed values by country, from 1992 to 2001. White robust errors in brackets. Distances... measured in thousands of kilometres. Alignment to US is the proportion of votes at UNGA that were aligned to American votes. Other controls: Exchange rate variation of local currency compared to US dollars, consumer prices variation, GDP growth, broad money growth, GDP per capita measured in thousands of 2010 US dollars, percentage of country's quota in total IMF quotas, proportions of imports from US and exports to US, temporary membership of the United Nations Security Council and a constant term. Column 1 includes no time dummies; column 2 includes a dummy for post1991 observations; column 3 includes a dummy if the contemporaneous US presidential mandate is Republican; column 4 include both Republican and post-1991 dummies. We consider only SBA.

Table 3 shows that our results hold for the period from 1970 to 1991, which are the years that precede the fall of the USSR. However, for this period, only the distance to non-Warsaw Pact countries is significant with the expected sign (Panel B). This supports the claim that the IMF acted in the 1980s and 1990s to contain the spread of communism in Africa and Asia, away from the Iron Curtain. We have found similar results for alternative periods of analysis: 19701989 and 1970-1990. The Warsaw Pact countries only became a priority in the 1990s, when Eastern European and former USSR republics launched their transition to market economies. 
Before that, the IMF acted to combat the spread of communism outside Europe. ${ }^{17}$ PANEL A Dependent variable: $\log$ (Number of conditions)

\begin{tabular}{lcc} 
& $(1)$ & $(2)$ \\
\hline Distance to Communist & 0.020 & 0.028 \\
& $(0.033)$ & $(0.034)$ \\
Alignment to US at UNGA & $-2.076^{* * *}$ & $-2.164^{* * *}$ \\
& $(0.260)$ & $(0.263)$ \\
\hline Republican dummy & & -0.125 \\
& & $(0.133)$ \\
\hline Other controls & Yes & Yes \\
Period & $1970-1991$ & $1970-1991$ \\
Adjusted $\mathrm{R}^{2}$ & 165 & 165 \\
\hline \hline
\end{tabular}

PANEL B Dependent variable: $\log$ (Number of conditions)

\begin{tabular}{lcc} 
& $(1)$ & $(2)$ \\
\hline Distance to Communist non-WPC & $0.040^{* *}$ & $0.047^{* *}$ \\
& $(0.020)$ & $(0.021)$ \\
Distance to Communist WPC & -0.007 & -0.006 \\
& $(0.032)$ & $(0.031)$ \\
Alignment to US at UNGA & $-2.143^{* * *}$ & $-2.260^{* * *}$ \\
& $(0.265)$ & $(0.276)$ \\
& $(0.006)$ & $(0.006)$ \\
\hline Republican dummy & & -0.167 \\
& & $(0.130)$ \\
\hline Other controls & Yes & Yes \\
Period & $1970-1991$ & $1970-1991$ \\
Adjusted $\mathrm{R}^{2}$ & 165 & 165 \\
\hline \hline
\end{tabular}

Table 3: Determinants of number of conditions (log): Period 1970-1991

Notes: ${ }^{* * *}$ and ${ }^{* * *}$ represent significance at 10,5 and 1 percent levels, respectively. White robust errors in brackets. Distances... measured in thousands of kilometres. Alignment to US is the proportion of votes at UNGA that were aligned to American votes. Other controls: Exchange rate variation of local currency compared to US dollars, consumer prices variation, GDP growth, broad money growth, GDP per capita measured in thousands of 2010 US dollars, percentage of country's quota in total IMF quotas, proportions of imports from US and exports to US, temporary membership of the United Nations Security Council and a constant term. Column 1 includes no time dummies; column 2 includes a dummy if the contemporaneous US presidential mandate is Republican.

\footnotetext{
${ }^{17}$ Our results are robust to the inclusion of country fixed-effects - see Appendix Tables D.2 and D.3. In Appendix Table D.4 we also consider models with year fixed effects. The coefficients of the variables of interest are qualitatively consistent with our overall results. Even though they are not statistically significant at standard levels, the t-stats of the coefficients are generally high (close to 1.5) for the period 1970-2001 (columns 1 and 2). The exception is the coefficient of the distance to communist members of the Warsaw Pact or the Comecon in column 2. This effect, however, is also generally not statistically significant in our main specification in Table 2 .
} 


\section{Robustness checks and placebo test}

As a robustness check, we change our main regressor. We now consider that neighboring Communist nations have different extensions of border shared, and hence, potentially influence borrowing countries by different degrees. We also take into account that the number of communist neighbors may have an impact on the number of conditions imposed by the IMF. Hence, our new variable of interest is which is simply the border shared with Communist neighbors divided by the total border of the borrowing country. Table 4 shows the results.

Dependent variable: $\log ($ Number of conditions)

\begin{tabular}{lcccc} 
& $(1)$ & $(2)$ & $(3)$ & $(4)$ \\
\hline Border shared with Communist & $-1.288^{* * *}$ & -0.443 & $-1.196^{* * *}$ & -0.482 \\
& $(0.480)$ & $(0.406)$ & $(0.448)$ & $(0.409)$ \\
Alignment to US at UNGA & $-2.632^{* * *}$ & $-1.966^{* * *}$ & $-2.801^{* * *}$ & $-2.041^{* * *}$ \\
& $(0.278)$ & $(0.240)$ & $(0.261)$ & $(0.254)$ \\
\hline Year $>1991$ & & $1.137^{* * *}$ & & $1.061^{* * *}$ \\
& & $(0.121)$ & & $(0.146)$ \\
Republican dummy & & & $-0.596^{* * *}$ & -0.109 \\
& & & $(0.111)$ & $(0.119)$ \\
\hline Other controls & Yes & Yes & Yes & Yes \\
Period & $1970-2001$ & $1970-2001$ & $1970-2001$ & $1970-2001$ \\
$N$ & 200 & 200 & 200 & 200 \\
Adjusted $\mathrm{R}^{2}$ & 0.322 & 0.537 & 0.409 & 0.537 \\
\hline \hline
\end{tabular}

Table 4: Robustness test: Conditionality and share of border, 1970-2001

Notes: ${ }^{*},{ }^{* *}$ and ${ }^{* * *}$ represent significance at 10,5 and 1 percent levels, respectively. Border shared.. has no unit. Alignment to US is the proportion of votes at UNGA that were aligned to American votes. Other controls: Exchange rate variation of local currency compared to US dollars, consumer prices variation, GDP growth, broad money growth, GDP per capita measured in thousands of 2010 US dollars, percentage of country's quota in total IMF quotas, proportions of imports from US and exports to US, temporary membership of the United Nations Security Council and a constant term. Column 1 includes no time dummies; column 2 includes a dummy for post1991 observations; column 3 includes a dummy if the contemporaneous US presidential mandate is Republican; column 4 includes both Republican and post-1991 dummies. We consider only SBA.

Overall, the estimations in Tables 4 corroborate our previous findings: the coefficient of the new variable of interest is negative and statistically significant in columns 1 and 3, which means that countries that shared larger extents of their frontiers with Communist countries borrowed from the IMF with fewer conditions. We further explore this relationship by determining the border shared with Communist neighbors, by alignment. Again, we divide the Communist countries among Warsaw Pact/Comecon membership. The results, presented in table 5, again corroborate our previous findings: The negative coefficient (statistically significant in columns 1 and 3) related to the border shared with Communist non-WPC countries suggests that the effect we discuss here is mainly related to distance to non-aligned countries. 
Dependent variable: $\log$ (Number of conditions)

(1)

\begin{tabular}{|c|c|c|c|c|}
\hline & & & & \\
\hline Border shared with Communist non-WPC $\ddagger$ & $\begin{array}{c}-1.286^{* * *} \\
(0.481)\end{array}$ & $\begin{array}{l}-0.439 \\
(0.407)\end{array}$ & $\begin{array}{c}-1.194^{* * *} \\
(0.449)\end{array}$ & $\begin{array}{l}-0.476 \\
(0.409)\end{array}$ \\
\hline Border shared with Communist WPC $\ddagger$ & $\begin{array}{l}-2.234 \\
(3.835)\end{array}$ & $\begin{array}{c}2.019 \\
(3.194)\end{array}$ & $\begin{array}{l}-2.280 \\
(3.579)\end{array}$ & $\begin{array}{c}1.747 \\
(3.213)\end{array}$ \\
\hline Alignment to US at UNGA & $\begin{array}{c}-2.628^{* * *} \\
(0.279)\end{array}$ & $\begin{array}{c}-1.971^{* * *} \\
(0.240)\end{array}$ & $\begin{array}{c}-2.796^{* * *} \\
(0.262)\end{array}$ & $\begin{array}{c}-2.041^{* * *} \\
(0.254)\end{array}$ \\
\hline Year > 1991 & & $\begin{array}{c}1.148^{* * *} \\
(0.122)\end{array}$ & & $\begin{array}{c}1.076^{* * *} \\
(0.148)\end{array}$ \\
\hline Republican dummy & & & $\begin{array}{c}-0.597^{* * *} \\
(0.111)\end{array}$ & $\begin{array}{l}-0.101 \\
(0.120)\end{array}$ \\
\hline Other controls & Yes & Yes & Yes & Yes \\
\hline Period & $1970-2001$ & $1970-2001$ & $1970-2001$ & $1970-2001$ \\
\hline$N$ & 200 & 200 & 200 & 200 \\
\hline Adjusted $\mathrm{R}^{2}$ & 0.318 & 0.536 & 0.406 & 0.536 \\
\hline
\end{tabular}

Table 5: Robustness test: Conditionality and border shared, by alignment, 1970-2001

Notes: ${ }^{*},{ }^{* *}$ and ${ }^{* * *}$ represent significance at 10,5 and 1 percent levels, respectively. Border shared.... $\ddagger$ indicates fixed values by country, from 1992 to 2001. Alignment to US is the proportion of votes at UNGA that were aligned to American votes. Other controls: Exchange rate variation of local currency compared to US dollars, consumer prices variation, GDP growth, broad money growth, GDP per capita measured in thousands of 2010 US dollars, percentage of country's quota in total IMF quotas, proportions of imports from US and exports to US, temporary membership of the United Nations Security Council and a constant term. Column 1 includes no time dummies; column 2 includes a dummy for post-1991 observations; column 3 includes a dummy if the contemporaneous US presidential mandate is Republican; column 4 includes both Republican and post-1991 dummies. We consider only SBA.

To check whether the relationship between proximity to communist countries and the IMF conditionality is valid only for the Cold War period, we conduct placebo tests using data from agreements sealed after 2001. We perform regressions using the same specification in table 2, but we remove from the sample the countries that once belonged to the USSR, Czechoslovakia or the Yugoslavian Federation, which disappeared with the end of the Cold War. This restriction allows us to balance the sample of countries that existed during and after the Cold War and prevents us from capturing the diplomatic pressures over the IMF related to the war on terror, which involved former soviet-republics in Central Asia. Table 6 shows that distance to communist or former communist countries did not play any role in IMF conditionality after 2001, which supports the conclusion that the Fund was a tool of the West in the fight against communism from the 1970 s to the $1990 \mathrm{~s}$. We repeat this exercise using also the distance to closest communist country, by alignment to the USSR. These results are in table 7 The absence of statistically relevant correlation between conditionality and distances during the post-9/11 period, furnishing more evidence that our hypothesis works for the 1970s-1990s only. 
Dependent variable: $\log ($ Number of conditions)

(1)

\begin{tabular}{lcc}
\hline Distance to Communist $\dagger$ & 0.068 & 0.069 \\
& $(0.077)$ & $(0.082)$ \\
Alignment to US at UNGA & 1.401 & 1.369 \\
& $(1.443)$ & $(1.595)$ \\
\hline Republican dummy & & -0.013 \\
& & $(0.267)$ \\
\hline Other controls & Yes & Yes \\
Period & $2002-2014$ & $2002-2014$ \\
$N$ & 40 & 40 \\
Adjusted $\mathrm{R}^{2}$ & 0.040 & 0.005 \\
\hline
\end{tabular}

Table 6: Determinants of number of conditions (log): Placebo test, period 2002-2014

Notes: ${ }^{* * *}$ and ${ }^{* * *}$ represent significance at 10,5 and 1 percent levels, respectively. $\dagger$ indicates fixed values by country, from 2002 to 2014. Non-corrected standard errors in brackets. Distances... measured in thousands of kilometres. Alignment to US is the proportion of votes at UNGA that were aligned to American votes. Other controls: Exchange rate variation of local currency compared to US dollars, consumer prices variation, GDP growth, broad money growth, GDP per capita measured in thousands of 2010 US dollars, percentage of country's quota in total IMF quotas, proportions of imports from US and exports to US, temporary membership of the United Nations Security Council and a constant term. We consider only SBA. Ex-members of USSR, Yugoslavia and Czechoslovakia were removed from sample. Column 1 includes no time dummies; column 2 includes a dummy if the contemporaneous US presidential mandate is Republican.

\section{Heterogeneous effects}

Our empirical exercise assumes that the IMF responded to distance linearly, reducing the number of conditions the closer borrowing countries were to the communist bloc. Hence, our approach ignores the fact that IMF's actions could be focused on countries under imminent communism threat, i.e., the effect we find could be stronger in regions surrounding the communist countries, and weaker as we move away from them. In order to address this issue, we break our sample intro tranches, allowing the relationship between the distance to communism and the number of IMF conditions to vary across the distribution of distance. To do this, we interact our main variable of interest, the distance to communist countries that were not part of the Warsaw Pact, with deciles of its distribution. ${ }^{18}$

Figure 5 shows that the coefficient of the interaction between our distance variable and the

\footnotetext{
${ }^{18}$ As explained earlier, our linear approach does not take into account geographical accidents such as the sea and deserts. Countries may be somewhat close in Euclidean terms, but apart in real terms. We consider that this exercise also addresses this geographical issue for the following reason: a decile turns out to be on average about $500 \mathrm{Km}$, which is small enough to avoid distortions arising from geographic accidents, but is large enough to scan the regions in which those non-aligned communist countries were located: Sub-Saharan Africa, Southeast Asia, and Central America, where most countries are territorially small. It is important to note that those countries were relatively small in a global scale (see list in the Appendix), and the Euclidean distance between their capital and the capital of neighbors were typically below 500 kilometres. The only exception is China.
} 
Dependent variable: $\log$ (Number of conditions)

(1)

\begin{tabular}{lcc}
\hline Distance to Communist non-WPC $\dagger$ & -0.132 & -0.131 \\
& $(0.086)$ & $(0.088)$ \\
Distance to Communist WPC $\dagger$ & 0.138 & 0.141 \\
& $(0.086)$ & $(0.088)$ \\
Alignment to US at UNGA & 3.680 & 2.657 \\
& $(2.473)$ & $(1.969)$ \\
\hline Republican dummy & & -0.042 \\
& & $(0.253)$ \\
\hline Other controls & Yes & Yes \\
Period & $2002-2014$ & $2002-2014$ \\
$N$ & 40 & 40 \\
Adjusted $\mathrm{R}^{2}$ & 0.184 & 0.184 \\
\hline \hline
\end{tabular}

Table 7: Determinants of number of conditions (log): Placebo test, period 2002-2014

Notes: ${ }^{* * *}$ and ${ }^{* * *}$ represent significance at 10,5 and 1 percent levels, respectively. $\dagger$ indicates fixed values by country, from 2002 to 2014. Non-corrected standard errors in brackets. Distances... measured in thousands of kilometres. Alignment to US is the proportion of votes at UNGA that were aligned to American votes. Other controls: Exchange rate variation of local currency compared to US dollars, consumer prices variation, GDP growth, broad money growth, GDP per capita measured in thousands of 2010 US dollars, percentage of country's quota in total IMF quotas, proportions of imports from US and exports to US, temporary membership of the United Nations Security Council and a constant term. We consider only SBA. Ex-members of USSR, Yugoslavia and Czechoslovakia were removed from sample. Column 1 includes no time dummies; column 2 includes a dummy if the contemporaneous US presidential mandate is Republican.

first decile is positive and significantly different from zero. This implies that the positive relationship between distance and conditionality was stronger for countries within the first decile compared to the rest of the sample. ${ }^{19}$ For higher deciles, however, the magnitudes of the effects are considerably lower and not significant in some cases. In other words, the IMF responded particularly strongly to the proximity to communism for countries within the first decile of the distribution of distance to non-aligned countries (approximately $500 \mathrm{~km}$ ), which included neighbors to communist countries, neighbors of neighbors. These results provide further evidence that the IMF was a tool in containing communism away from the Warsaw Pact. ${ }^{20}$

\footnotetext{
${ }^{19}$ An example of this relationship comprises the SBAs the IMF arranged with Ghana and Morocco in 1983. For both countries, the closest Communist - and non-Soviet aligned - capital was Porto Novo, in Benin, circa 300 and $2400 \mathrm{~km}$ away from Accra and Casablanca, respectively. Using our buffer estimates for the distance to closest Communist non-WPC coefficients, if we increase the distance to Benin's capital by $100 \mathrm{~km}$ would lead to circa $67 \%$ more conditions for Ghana, but only $0.04 \%$ more conditions for Morocco.

${ }^{20}$ The results do not follow the same pattern when we consider all or aligned communist nations - see Figures F. 1 and F. 2 for the two cases.
} 


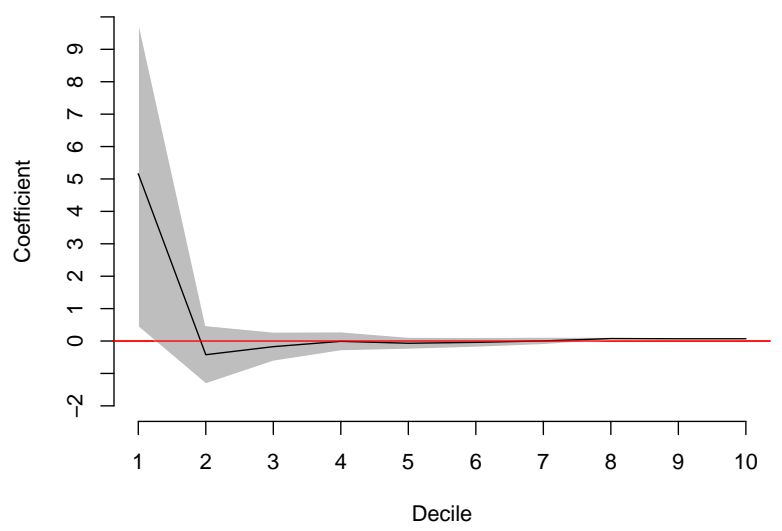

Figure 5: Coefficient of the regression of conditionality against Distance to Communist non-WPC and controls, on decile subsamples. Shaded area represents the $90 \%$ confidence level estimate. See table F. 2 for full description of the exercise.

\section{Conclusion}

The IMF imposed fewer conditions when lending to countries that were close to the communist bloc during the Cold War. That was especially the case in Africa and Asia, where the conflict was more volatile, away from Europe's already established Iron Curtain. This result suggests that the West - the United States and its allies - used the Fund as a tool to combat communism, strengthening the governments that were more exposed to its global spread both financially and politically. The conclusion that the IMF was one of the West's tools in the Cold War is in line with the literature, according to which the US government imposes an agenda on the IMF to achieve its foreign policy interests.

However, the previous literature focuses on the most recent period in their assessment of the IMF and global politics. This article extends the period of analysis back from the 1990s to the 1970s, a contribution that derives from new primary sources - the letters of intent from 1970 to 1993 - that are available in the IMF Digital Archive. In doing so, we show that the Fund was also subject to the pressure from the West's diplomacy in the past, when the Cold War divided the world between the West and countries under the growing influence of communism.

Our results show that the IMF only acted against communism before 2001, after which we find no effect of distance to communist countries on the IMF's conditionality. It is likely that, after the 9/11 attacks, the Fund steered its strategy towards the fight against terrorism, as did the US aid budget (Fleck and Kilby, 2010). However, this topic requires further empirical investigation.

\section{Acknowledgements}

We thank Bernardo Guimarães, Umberto Mignozzetti and Thomas Stubbs for crucial help. We appreciate the helpful comments from Fernanda Estevan, Paulo Pichetti, Felipe Loureiro, Gianfranco Caterina, Samuel Bazzi 
and Maximiliano Garcia. We also thank the participants of the São Paulo School of Economics' Seminar and the 6th Brazilian Economic History Workshop.

Funding: This work was supported by CAPES (Brazilian Agency for Higher Education).

\section{References}

Alesina, A. and D. Dollar (2000). Who gives foreign aid to whom and why? Journal of Economic Growth 5(1), 33-63.

Andersen, T. B., T. Harr, and F. Tarp (2006). On US politics and IMF lending. European Economic Review 50(7), 1843-1862.

Auvinen, J. Y. (1996). IMF intervention and political protest in the Third World: A conventional wisdom refined. Third World Quarterly 17(3), 377-400.

Barro, R. and J.-W. Lee (2005). Imf programs: Who is chosen and what are the effects? Journal of Monetary Economics 52(7), 1245-1269.

Berger, D., W. Easterly, N. Nunn, and S. Satyanath (2013). Commercial imperialism? political influence and trade during the cold war. American Economic Review 103(2), 863-96.

Collier, P., P. Guillaumont, S. Guillaumont, and J. W. Gunning (1997, sept.). Redesigning conditionality. World Development 25(9), 1399-1407.

Copelovitch, M. S. (2010). Master or servant? common agency and the political economy of imf lending. International Studies Quarterly 54(1), 49-77.

Dodds, K. (2007). Cold War Geopolitics, Chapter 14, pp. 204-218. John Wiley and Sons, Ltd.

Dreher, A. (2004, jun). A Public Choice Perspective of IMF and World Bank Lending and Conditionality. Public Choice 119(3/4), 445-464.

Dreher, A. (2009). IMF conditionality: Theory and evidence. Public Choice 141(1-2), 233-267.

Dreher, A. and N. M. Jensen (2007, feb). Independent Actor or Agent? An Empirical Analysis of the Impact of U.S. Interests on International Monetary Fund Conditions. The Journal of Law and Economics 50(1), 105-124.

Dreher, A., V. Lang, B. P. Rosendorff, and J. R. Vreeland (2018). Buying votes and international organizations: The dirty work-hypothesis.

Dreher, A., J.-E. Sturm, and J. R. Vreeland (2009a). Development aid and international politics: Does membership on the un security council influence world bank decisions? Journal of Development Economics 88(1), 1-18. 
Dreher, A., J.-E. Sturm, and J. R. Vreeland (2009b). Global horse trading: IMF loans for votes in the United Nations Security Council. European Economic Review 53(7), 742-757.

Dreher, A., J.-E. Sturm, and J. R. Vreeland (2015). Politics and IMF Conditionality. Journal of Conflict Resolution 59(1), 120-148.

Fleck, R. K. and C. Kilby (2010). Changing aid regimes? U.S. foreign aid from the Cold War to the War on Terror. Journal of Development Economics 91(2), 185-197.

Fordham, B. O. (2007). The evolution of republican and democratic positions on cold war military spending: A historical puzzle. Social Science History, 603-636.

Gaddis, J. L. (2006). The Cold War: a new history. Penguin.

Gould, E. R. (2003). Money talks: Supplementary financiers and IMF conditionality. International Organization 57(3), 551-586.

Gould, E. R. (2006). Money Talks: the International Monetary Fund, Conditionality, and Supplementary Financiers. Stanford, California: Stanford University Press.

Guimaraes, B. and C. E. Ladeira (2018). The determinants of IMF fiscal conditionalities: economics or politics? Working Paper.

Haywood, J. (2011). The new atlas of world history: Global Events at a glance. Princeton University Press Princeton.

Head, K. and T. Mayer (2014). Gravity equations: Workhorse, toolkit, and cookbook. In Handbook of international economics, Volume 4, pp. 131-195. Elsevier.

International Monetary Fund (2002). Guidelines on Conditionality. Technical report, International Monetary Fund, Washington, D. C.

International Monetary Fund (2011). Articles of Agreement. Washington, D. C.: International Monetary Fund.

Ivanova, A., W. Mayer, A. Mourmouras, and G. Anayiotos (2003). What Determines the Implementation of IMF-Supported Programs? .

Kedar, C. (2015). Salvador Allende and the International Monetary Fund, 1970-1973: The Depoliticisation and Technocratisation of Cold War Relations. Journal of Latin American Studies 47(4), 717-747.

Kedar, C. (2017). The International Monetary Fund and the Chilean Chicago Boys, 1973-7: Cold Ties between Warm Ideological Partners. Journal of Contemporary History 0(0), 1-23. 
Kentikelenis, A. E., T. H. Stubbs, and L. P. King (2016). Imf conditionality and development policy space, 1985-2014. Review of International Political Economy 23(4), 543-582.

Kersting, E. and C. Kilby (2016). With a little help from my friends: Global electioneering and world bank lending. Journal of Development Economics 121(C), 153-165.

Kilby, C. (2013). An empirical assessment of informal influence in the world bank. Economic Development and Cultural Change 61(2), 431 - 464.

Kinder, H. and W. Hilgemann (2003). The Penguin Atlas of World History (3 ed.). London: Penguin Books.

Lang, V. F. and A. F. Presbitero (2018). Room for discretion? Biased decision-making in international financial institutions. Journal of Development Economics 130(C), 1-16.

Lis, P. (2014). Terrorism, armed conflict and foreign aid. Peace Economics, Peace Science and Public Policy 20(4), 655-667.

McKeown, T. J. (2009). How us decision-makers assessed their control of multilateral organizations, 1957-1982. The Review of International Organizations 4(3), 269-291.

Momani, B. (2004). American politicization of the international monetary fund. Review of International Political Economy 11(5), 880-904.

Moon, C., B. Woo, et al. (2014). Curse of friendship: Imf program, friendship with the united states, and foreign direct investment.

Neumayer, E. (2008, jun). Distance, power and ideology: diplomatic representation in a world of nation-states. Area 40(2), 228-236.

Oatley, T. and J. Yackee (2004, Sep). American Interests and IMF Lending. International Politics 41(3), 415-429.

Oneal, J. R. and B. Russett (1999, sep). Is the liberal peace just an artifact of cold war interests? Assessing recent critiques. International Interactions 25(3), 213-241.

Polak, J. J. (1991). The Changing Nature of IMF Conditionality. Essays in International Finance 184, 84.

Reynaud, J. and J. Vauday (2009). Geopolitics and international organizations: An empirical study on IMF facilities. Journal of Development Economics 89(1), 139-162.

Sant'Anna, A. A. and L. Weller (2020). The threat of communism during the cold war: A constraint to income inequality? Comparative Politics 52(3), 359-393. 
Steinwand, M. C. and R. W. Stone (2008, jun). The International Monetary Fund: A review of the recent evidence. The Review of International Organizations 3(2), 123-149.

Stiles, K. W. (1990). IMF conditionality: Coercion or compromise? World Development 18(7), 959-974.

Stone, R. W. (2004). The Political Economy of IMF Lending in Africa. The American Political Science Review 98(4), 577-591.

Stone, R. W. (2008). The Scope of IMF Conditionality. International Organization 62(04), 589.

Strezhnev, A. and A. Voeten (2013). United Nations General Assembly voting data. Available at http://hdl.handle.net/1902.1/12379.

Thacker, S. (1999). The high politics of IMF lending. World Politics 52(1), 38-75.

Weidmann, N. B., D. Kuse, and K. S. Gleditsch (2010). The geography of the international system: The cshapes dataset. International Interactions 36(1), 86-106.

Westad, O. A. (2005). The global Cold War: third world interventions and the making of our times. Cambridge University Press. 


\section{Appendices}

\section{A How we built our database}

We explain below the steps we made to codify the database from 1970 to 1985 and illustrate all of them with a particular case: Brazil's 1972 SBA loan. ${ }^{21}$

To construct our database, the first step was collecting the documents that contained information about the loan agreements that interested us. We completed this step with a program that accessed IMF Archives and downloaded every document indexed under tags that identified an arrangement. Since the program was not refined, it grabbed many uninteresting documents. To get rid of them, we conducted a manual cleaning, restricting our collection of documents mainly to letters of intent. The Fund codifies this set of documents under the "EBS" series, and all of them have a front page like the one presented in figure A.1.

Next, our task was identifying the basic data about the agreement, i.e., the type of loan, the country involved and the date of the document. We see clearly these pieces of information in figure A.1.

Afterward, we identified the amount lent to the borrower country, when was the start date and how long was the loan term. We usually found them the second page of the arrangement document, where the main terms and rules guiding the loan are listed. Figure A.2 exemplifies it. The three pieces of information are exposed in the fourth paragraph.

In the terms of the loan, we could also first identify the information about which are the binding or indicative conditions ruling the agreement. Usually, this part of the text exacts which paragraphs in the letter of intent contain every particular condition. Here, in Brazil's letter, we read that the paragraphs $3,11,12$ and 14 of the letter of intent that are the ones relevant to the agreement. Thus, we only considered the conditions mentioned in this list; we ignored any information presented along other parts of the letter of intent.

The next part consisted of reading the relevant paragraphs and extracting the characteristics of the conditions from them. This includes the type of condition, whether it is binding and the policy area it related to. To exhibit an example, figure A.3 presents the third paragraph of the letter of intent we are discussing.

Since the condition there presented is a ceiling for monetary authorities' net domestic assets, we class it, following the key made by Kentikelenis et al. (2016), as financial sector, monetary policy and Central Bank issues, respectively. Besides that, we read that this ceiling imposes a limit for every quarter of 1972. Thus, the contribution of this net domestic assets limit to the sum of conditions that represents this agreement was 4. Subsequently, we repeated this step for every other paragraph mentioned in the agreements text.

After repeating this algorithm of identification and codification of conditions for every docu-

\footnotetext{
${ }^{21}$ Available at IMF Archives.
} 
DOCUMENT OF INTERNATIONAL MONETARY FUND AND NOT FOR PUBLIC USE

$\mathrm{EBS} / 72 / 37$

Supplement 1

CONEIDENTIAL

March 3, 1972

To: $\quad$ Members of the Executive Board

From: The Acting Secretary

Subject: Brazil - Stand-By Arrangement

Attached for the records of the Executive Directors is the text of the stand-by arrangement for. Brazil agreed at Executive Board Meeting $72 / 19$, March 3, 1972.

Att: (1)

Figure A.1: Brazil's 1972 SBA front page 


\section{Stand-By Arrangement - Brazil}

1. Annexed hereto is a letter dated January 27, 1972 from the Minister of Finance of Brazil setting forth the objectives and policies which the authorities of Brazil will pursue.

2. The International Monetary Fund grants this stand-by arrangement to support these objectives and policies.

3. Brazil will remain in close consultation with the Fund during the period of the stand-by arrangement and, in particular, will consult the Fund in accordance with paragraph 14 of the annexed letter and paragraph 5 below. These consultations may include correspondence and visits of of ficials of the Fund to Brazil or of representatives of Brazil to Washington, D.C. For the purposes of these consultations, Brazil will keep the Fund informed of developments in the exchange, trade, credit, and fiscal situations through reports a.t intervals or dates requested by the Fund.

4. For a period of one year from March 3, 1972, Brazil will have the right, after making full use of any gold tranche that it may have, to make purchases from the Fund in the currencies of other members in exchange for its own currency in an amount equivalent to 50 million units of special drawing rights. The amounts available in accordance with this paragraph 4 shall be augmented by amounts equivalent to repurchases in respect of purchases under the stand-by arrangement, unless when any such repurchase is made, Brazil informs the Fund that it does not wish the stand-by arrangement to be augmented by the amount of that repurchase.

5. During any period of the stand-by arrangement in which the criteria in paragraphs 3, 11, and 12 of the annexed letter are not being observed, Brazil will consult the Fund, at the request of the Managing Director, regarding the appropriate measures to be adopted in order to achieve the objectives of the program.

6. Brazil will pay charges for this stand-by arrangement in accordance with Executive Board Decisions Nos. 270-(53/95), adopted December 23, 1953; 876-(59/15), adopted April 27, 1959; and 1345-(62/23), adopted May 23, 1962.

7. Brazil will have the right to engage in the transactions covered by this stand-by arrangement without further review by the Fund. This right can be suspended only with respect to requests received by the Fund after (a) a formal ineligibility, or (b) a decision of the Executive Board to suspend transactions, either generally (under Article XVI, Section $1(\mathrm{a})$ (ii)) or in order to consider a proposal, made by an Executive Director or the Managing Director, formally to suppress or to limit the eligibility of Brazil. When notice of a decision of formal ineligibility or of a decision to consider a proposal is given pursuant to this paragraph 7 , purchases under this stand-by arrangement will be resumed only after consultation has taken place between the Fund and Brazil and understandings have been reached regarding the circumstances in which such purchases can be resumed.

Figure A.2: Brazil's 1972 SBA second page 


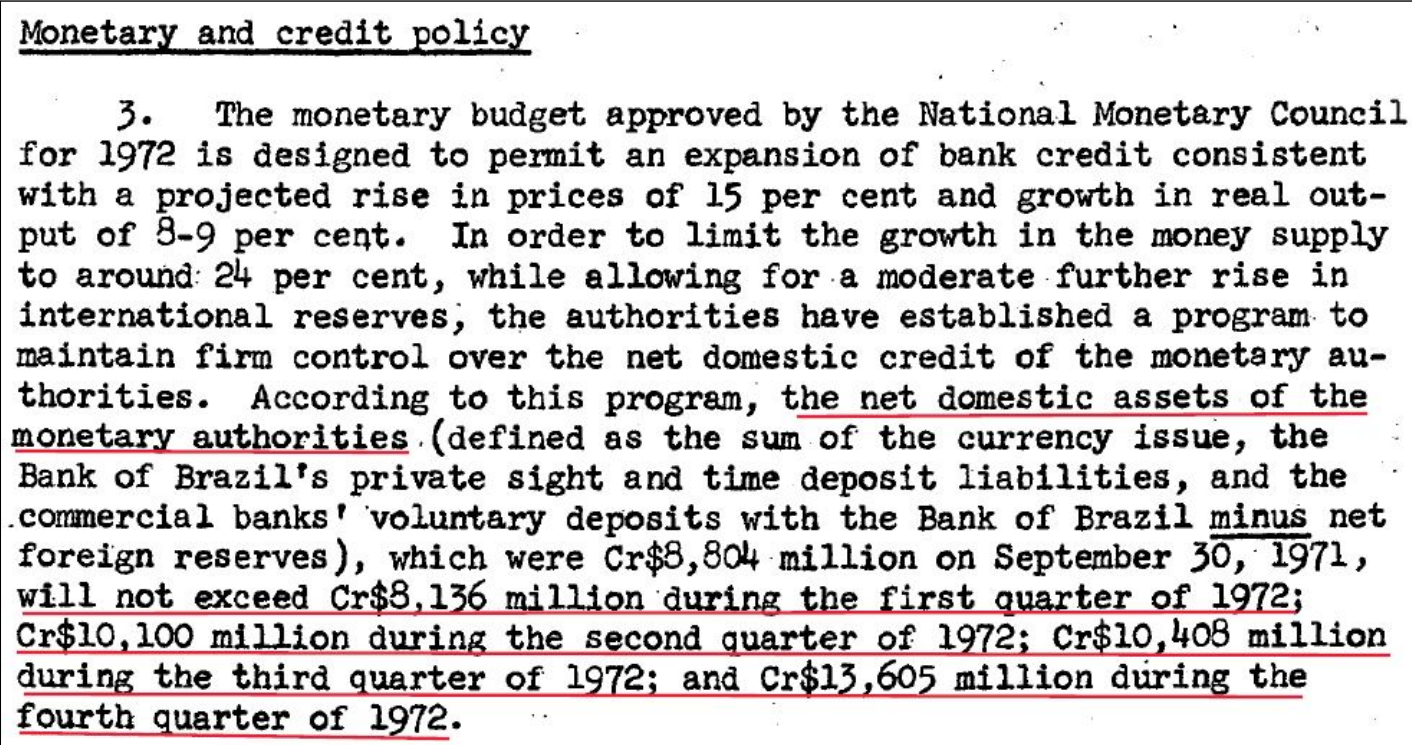

Figure A.3: Third paragraph of Brazil's 1972 letter of intent

The underlined sections indicate the parts where the condition terms are explicitly stated - quarterly superior bounds for net domestic assets.

mented agreement, and after joining our data with Kentikelenis et al.'s, we finished constructing our database of agreements.

Besides this way of summing conditions, we also organized information on areas on which these conditions focus (e. g. state-owned enterprises, fiscal policy or external sector). However, due to the nature and extent of the present work, we did not advance in the analysis this dimension. 


\section{B Other measures of conditionality}

We present three other ways to sum conditions.

- $\mathrm{C} 1$ is the criterion we used, considering every condition mentioned in the documents as well as the frequency some conditions had to be applied.

- C2 criterion considers every condition mentioned in the documents but ignores the frequency some conditions are applied. A quarterly fiscal target for a year, for example, is counted as 1 .

- C3 criterion considers only binding conditions. It also considers the frequency some conditions had to be applied.

- C4 criterion considers only binding conditions and ignores the frequency some conditions had to be applied.

We see that all these measures are highly correlated (table B.2).

\begin{tabular}{cccccc}
\hline & N & Mean & Std. dev. & Skewness & Kurtosis \\
\hline C1 & 923 & 72.87 & 79.26 & 1.54 & 1.92 \\
C2 & 923 & 24.34 & 25.72 & 2.02 & 5.63 \\
C3 & 923 & 44.72 & 44.59 & 1.46 & 1.98 \\
C4 & 923 & 12.94 & 14.66 & 2.92 & 13.10 \\
\hline
\end{tabular}

Table B.1: Different counts: Descriptive statistics

Notes: Table presents summary statistics for different counts of the number of conditions in SBA's, C1, C2, C3 and $\mathrm{C} 4$. We calculate the number of observations, the mean, the standard deviation, the skewness and the kurtosis. We consider the SBA sample and the whole available period (1970-2014).

\begin{tabular}{c|cccc} 
& $\mathrm{C} 1$ & $\mathrm{C} 2$ & $\mathrm{C} 3$ & $\mathrm{C} 4$ \\
\hline $\mathrm{C} 1$ & 1 & 0.8668822 & 0.9224243 & 0.7449528 \\
$\mathrm{C} 2$ & & 1 & 0.8483255 & 0.8812597 \\
$\mathrm{C} 3$ & & & 1 & 0.8450591 \\
$\mathrm{C} 4$ & & & & 1
\end{tabular}

Table B.2: Different counts: Correlations

Notes: Table presents correlations among different counts of the number of conditions in SBA's, C1, C2, C3 and C4. We consider the SBA sample and the whole available period (1970-2014). 


\section{Descriptive statistics}

Here we present the descriptive statistics tables of the data sample used. They comprehend only the complete observations, e. g., the data on agreements for which all the analysed variables were available.

\begin{tabular}{lccccccc}
\hline \hline & $\mathrm{N}$ & Mean & Median & Max. & Min. & Std. dev. & Skewness \\
\hline Number of conditions & 207 & 30.850 & 20 & 1 & 305 & 33.473 & 3.466 \\
Distance to Communist & 207 & 2.426 & 1.603 & 0 & 10.189 & 2.175 & 1.768 \\
Distance to Communist non-WPC $\ddagger$ & 207 & 3.870 & 2.475 & 0 & 10.634 & 3.547 & 0.808 \\
Distance to Communist WPC $\ddagger$ & 207 & 3.133 & 2.617 & 0.154 & 10.479 & 1.964 & 0.834 \\
Alignment to US at UNGA & 207 & 0.395 & 0.344 & 0.091 & 0.972 & 0.214 & 0.495 \\
Temporary membership at UNSC & 207 & 0.116 & 0 & 0 & 1 & 0.321 & 2.382 \\
Exchange rate variation & 207 & 33.604 & 6.947 & -99.995 & $1,400.000$ & 125.312 & 8.525 \\
Broad money growth & 207 & 24.733 & 17.469 & -20.621 & 334.008 & 38.617 & 5.013 \\
Consumer prices variation & 207 & 24.716 & 12.390 & -3.113 & 374.735 & 45.100 & 5.319 \\
GDP growth (per cent) & 207 & 2.510 & 3.749 & -24.049 & 18.665 & 5.486 & -1.008 \\
GDP per capita (2010) & 207 & 2.831 & 2.082 & 0.167 & 17.056 & 2.809 & 2.695 \\
Proportion of quota & 207 & 0.154 & 0.085 & 0.002 & 1.211 & 0.167 & 3.019 \\
Proportion of exports to US (per cent) & 207 & 24.220 & 19.796 & 0 & 88.415 & 19.342 & 0.632 \\
Proportion of imports from US (per cent) & 207 & 21.256 & 19.016 & 1.311 & 74.476 & 15.364 & 0.731 \\
\hline
\end{tabular}

Table C.1: Descriptive statistics for the SBA sample - 1970-2001

Notes: Table presents summary statistics for several variables used in our exercise. We calculate the number of observations, the mean, the median, the maximum, the minimum, the standard deviation and the skewness. We consider the SBA sample and the whole available period (1970-2011).

Next, we present the descriptive statistics for the Cold War data, only. Again, they refer to complete observations, only.

\begin{tabular}{lccccccc}
\hline \hline & $\mathrm{N}$ & Mean & Median & Max. & Min. & Std. dev. & Skewness \\
\hline Number of conditions & 165 & 21.455 & 14 & 1 & 305 & 27.428 & 7.026 \\
Distance to Communist & 165 & 1.970 & 1.598 & 0 & 8.687 & 1.561 & 1.600 \\
Distance to Communist non-WPC & 165 & 4.374 & 2.750 & 0 & 10.634 & 3.767 & 0.518 \\
Distance to Communist WPC & 165 & 3.362 & 3.130 & 0.750 & 10.479 & 1.992 & 0.788 \\
Alignment to US at UNGA & 165 & 0.415 & 0.404 & 0.091 & 0.972 & 0.230 & 0.283 \\
Temporary membership at UNSC & 165 & 0.121 & 0 & 0 & 1 & 0.327 & 2.300 \\
Exchange rate variation & 165 & 36.009 & 6.877 & -21.174 & $1,400.000$ & 137.709 & 7.986 \\
Broad money growth & 165 & 24.304 & 17.557 & -20.621 & 334.008 & 40.439 & 5.249 \\
Consumer prices variation & 165 & 25.019 & 12.444 & -3.113 & 374.735 & 47.499 & 5.442 \\
GDP growth (per cent) & 165 & 2.691 & 3.831 & -24.049 & 14.577 & 5.404 & -1.340 \\
GDP per capita (2010) & 165 & 2.562 & 1.706 & 0.167 & 17.056 & 2.615 & 3.311 \\
Proportion of quota & 165 & 0.156 & 0.088 & 0.004 & 1.211 & 0.169 & 3.356 \\
Proportion of exports to US (per cent) & 165 & 23.818 & 19.690 & 0 & 75.146 & 18.707 & 0.497 \\
Proportion of imports from US (per cent) & 165 & 20.999 & 19.412 & 1.311 & 70.679 & 14.321 & 0.515 \\
\hline
\end{tabular}

Table C.2: Descriptive statistics for the SBA sample - 1970-1991

Notes: Table presents descriptive statistics for several variables used in our exercise. We calculate the number of observations, the mean, the median, the maximum, the minimum, the standard deviation and the skewness. We consider the SBA sample and the Cold war period (1970-1991). 


\section{Additional results}

Dependent variable: $\log$ (Number of conditions)

(1)

(2)

(3)

(4)

\begin{tabular}{lcccc}
\hline Alignment to US at UNGA & $-2.517^{* * *}$ & $-1.917^{* * *}$ & $-2.694^{* * *}$ & $-1.990^{* * *}$ \\
& $(0.259)$ & $(0.249)$ & $(0.253)$ & $(0.256)$ \\
\hline Other controls & Yes & Yes & Yes & Yes \\
Republican dummy & & & $-0.629^{* * *}$ & -0.117 \\
& & & $(0.117)$ & $(0.112)$ \\
\hline Time controls & year & year & year & year \\
Period & $1970-2001$ & $1970-2001$ & $1970-1991$ & $1970-1991$ \\
$N$ & 207 & 207 & 207 & 207 \\
$\mathrm{R}^{2}$ & 0.334 & 0.561 & 0.427 & 0.563 \\
Adjusted $\mathrm{R}^{2}$ & 0.300 & 0.536 & 0.395 & 0.536 \\
\hline \hline
\end{tabular}

Table D.1: Determinants of number of conditions (log): New estimation of established results

Notes: ${ }^{*}{ }^{* *}$ and ${ }^{* * *}$ represent significance at 10,5 and 1 percent levels, respectively. White robust errors in brackets. Alignment to US is the proportion of votes at UNGA that were aligned to American votes. Other controls: Exchange rate variation of local currency compared to US dollars, consumer prices variation, GDP growth, broad money growth, GDP per capita measured in thousands of 2010 US dollars, percentage of country's quota in total IMF quotas, proportions of imports from US and exports to US, temporary membership of the United Nations Security Council and a constant term. Column 1 includes no time dummies; column 2 includes a dummy for post1991 observations; column 3 includes a dummy if the contemporaneous US presidential mandate is Republican; column 4 includes both Republican and post-1991 dummies. We consider only SBA. 
Dependent variable: $\log$ (Number of conditions)

(1)

\begin{tabular}{|c|c|c|c|c|}
\hline & (1) & (2) & (3) & (4) \\
\hline Distance to Communist non-WPC $\ddagger$ & $\begin{array}{c}0.006 \\
(0.025)\end{array}$ & $\begin{array}{c}0.072^{* * *} \\
(0.023)\end{array}$ & $\begin{array}{l}0.053^{* *} \\
(0.026)\end{array}$ & $\begin{array}{c}0.096^{* * *} \\
(0.023)\end{array}$ \\
\hline Distance to Communist WPC $\ddagger$ & $\begin{array}{c}-0.361^{* *} \\
(0.149)\end{array}$ & $\begin{array}{c}0.033 \\
(0.148)\end{array}$ & $\begin{array}{l}-0.193 \\
(0.145)\end{array}$ & $\begin{array}{c}0.106 \\
(0.141)\end{array}$ \\
\hline Alignment to US at UNGA & $\begin{array}{c}-2.008^{* * *} \\
(0.369)\end{array}$ & $\begin{array}{c}-2.052^{* * *} \\
(0.338)\end{array}$ & $\begin{array}{c}-2.541^{* * *} \\
(0.385)\end{array}$ & $\begin{array}{c}-2.403^{* * *} \\
(0.369)\end{array}$ \\
\hline Year > 1991 & & $\begin{array}{c}1.088^{* * *} \\
(0.191)\end{array}$ & & $\begin{array}{c}0.980^{* * *} \\
(0.181)\end{array}$ \\
\hline Republican dummy & & & $\begin{array}{c}-0.534^{* * *} \\
(0.171)\end{array}$ & $\begin{array}{c}-0.356^{* *} \\
(0.149)\end{array}$ \\
\hline Country FE & Yes & Yes & Yes & Yes \\
\hline Other controls & Yes & Yes & Yes & Yes \\
\hline Period & 1970-2001 & $1970-2001$ & $1970-2001$ & 1970-2001 \\
\hline$N$ & 197 & 197 & 197 & 197 \\
\hline Adjusted $\mathrm{R}^{2}$ & 0.527 & 0.611 & 0.559 & 0.623 \\
\hline
\end{tabular}

Table D.2: Determinants of number of conditions (log): Country fixed effects

Notes: ${ }^{* * *}$ and ${ }^{* * *}$ represent significance at 10,5 and 1 percent levels, respectively. $\ddagger$ indicates fixed values by country, from 1992 to 2001. White robust errors in brackets. Distances... measured in thousands of kilometres. Alignment to US is the proportion of votes at UNGA that were aligned to American votes. Other controls: Exchange rate variation of local currency compared to US dollars, consumer prices variation, GDP growth, broad money growth, GDP per capita measured in thousands of 2010 US dollars, percentage of country's quota in total IMF quotas, proportions of imports from US exports to US, imports divided reserves, temporary membership of the United Nations Security Council and a constant. Column 1 includes no time dummies; column 2 includes a dummy for post-1991 observations; column 3 includes a dummy if the contemporaneous US presidential mandate is Republican; column 4 includes both Republican and post-1991 dummies. We consider only SBA. 
PANEL A

Dependent variable: $\log$ (Number of conditions)

(1)

\begin{tabular}{lcc} 
& $(1)$ & $(2)$ \\
\hline Distance to Communist & -0.403 & -0.415 \\
& $(0.292)$ & $(0.310)$ \\
Alignment to US at UNGA & $-1.697^{* * *}$ & $-1.659^{* * *}$ \\
& $(0.364)$ & $(0.402)$ \\
\hline Republican dummy & & 0.036 \\
& & $(0.177)$ \\
\hline Country FE & Yes & Yes \\
Other controls & Yes & Yes \\
Period & $1970-1991$ & $1970-1991$ \\
$N$ & 165 & 165 \\
Adjusted $\mathrm{R}^{2}$ & 0.403 & 0.398 \\
\hline \hline
\end{tabular}

PANEL B

Dependent variable: $\log$ (Number of conditions)

(1)

(2)

\begin{tabular}{lcc}
\hline Distance to Communist non-WPC & $0.060^{* *}$ & $0.080^{* * *}$ \\
& $(0.028)$ & $(0.029)$ \\
Distance to Communist WPC & 0.364 & 0.388 \\
& $(0.260)$ & $(0.258)$ \\
Alignment to US at UNGA & $-2.112^{* * *}$ & $-2.384^{* * *}$ \\
& $(0.404)$ & $(0.432)$ \\
\hline Republican dummy & & $-0.278^{*}$ \\
\hline Country FE & & $(0.165)$ \\
Other controls & Yes & Yes \\
Period & Yes & Yes \\
$N$ & $1970-1991$ & $1970-1991$ \\
Adjusted $\mathrm{R}^{2}$ & 165 & 165 \\
\hline \hline
\end{tabular}

Table D.3: Determinants of number of conditions (log): Period 1970-1991 with country fixed-effects

Notes: ${ }^{* * *}$ and ${ }^{* * *}$ represent significance at 10,5 and 1 percent levels, respectively. White robust errors in brackets. Distances... measured in thousands of kilometres. Alignment to US is the proportion of votes at UNGA that were aligned to American votes. Other controls: Exchange rate variation of local currency compared to US dollars, consumer prices variation, GDP growth, broad money growth, GDP per capita measured in thousands of 2010 US dollars, percentage of country's quota in total IMF quotas, proportions of imports from US and exports to US, temporary membership of the United Nations Security Council and a constant term. Column 1 includes no time dummies; column 2 includes a dummy if the contemporaneous US presidential mandate is Republican. 
Dependent variable: $\log$ (Number of conditions)

(1)

$(0.022)$

Distance to Communist non-WPC $\ddagger$

Distance to Communist WPC $\ddagger$

Alignment to US at UNGA

\begin{tabular}{lcccc}
\hline Distance to communist & 0.033 & & 0.010 & \\
& $(0.022)$ & & $(0.031)$ & \\
Distance to Communist non-WPC $\ddagger$ & & 0.031 & & 0.003 \\
& & $(0.020)$ & & $(0.022)$ \\
Distance to Communist WPC $\ddagger$ & & -0.021 & & -0.003 \\
& & $(0.021)$ & & $(0.027)$ \\
Alignment to US at UNGA & -0.699 & $-0.987^{*}$ & -0.595 & -0.616 \\
& $(0.543)$ & $(0.581)$ & $(0.613)$ & $(0.622)$ \\
\hline Year fixed effects & Yes & Yes & Yes & Yes \\
\hline Other controls & Yes & Yes & Yes & Yes \\
Period & $1970-2001$ & $1970-2001$ & $1970-1991$ & $1970-1991$ \\
$N$ & 207 & 207 & 165 & 165 \\
Adjusted $\mathrm{R}^{2}$ & 0.665 & 0.666 & 0.523 & 0.519 \\
\hline \hline
\end{tabular}

(2)

(3)

$(0.031)$

\begin{tabular}{lcccc}
\hline Distance to communist & 0.033 & & 0.010 & \\
& $(0.022)$ & & $(0.031)$ & \\
Distance to Communist non-WPC $\ddagger$ & & 0.031 & & 0.003 \\
& & $(0.020)$ & & $(0.022)$ \\
Distance to Communist WPC $\ddagger$ & & -0.021 & & -0.003 \\
& & $(0.021)$ & & $(0.027)$ \\
Alignment to US at UNGA & -0.699 & $-0.987^{*}$ & -0.595 & -0.616 \\
& $(0.543)$ & $(0.581)$ & $(0.613)$ & $(0.622)$ \\
\hline Year fixed effects & Yes & Yes & Yes & Yes \\
\hline Other controls & Yes & Yes & Yes & Yes \\
Period & $1970-2001$ & $1970-2001$ & $1970-1991$ & $1970-1991$ \\
$N$ & 207 & 207 & 165 & 165 \\
Adjusted $\mathrm{R}^{2}$ & 0.665 & 0.666 & 0.523 & 0.519 \\
\hline \hline
\end{tabular}

(4)

Table D.4: Determinants of number of conditions (log): Year fixed effects

Notes: ${ }^{*},{ }^{* *}$ and ${ }^{* * *}$ represent significance at 10,5 and 1 percent levels, respectively. $\ddagger$ indicates fixed values by country, from 1992 to 2001. White robust errors in brackets. Distances... measured in thousands of kilometres. Alignment to US is the proportion of votes at UNGA that were aligned to American votes. Other controls: Exchange rate variation of local currency compared to US dollars, consumer prices variation, GDP growth, broad money growth, GDP per capita measured in thousands of 2010 US dollars, percentage of country's quota in total IMF quotas, proportions of imports from US and exports to US and temporary membership of the United Nations Security Council. Columns 1 and 2 consider the period 1970-2001. Columns 3 and 4 consider the period 1970-1991. All columns include year fixed effects. We consider only SBA. 


\section{E Additional descriptive figures}

\section{E.1 Quotas}

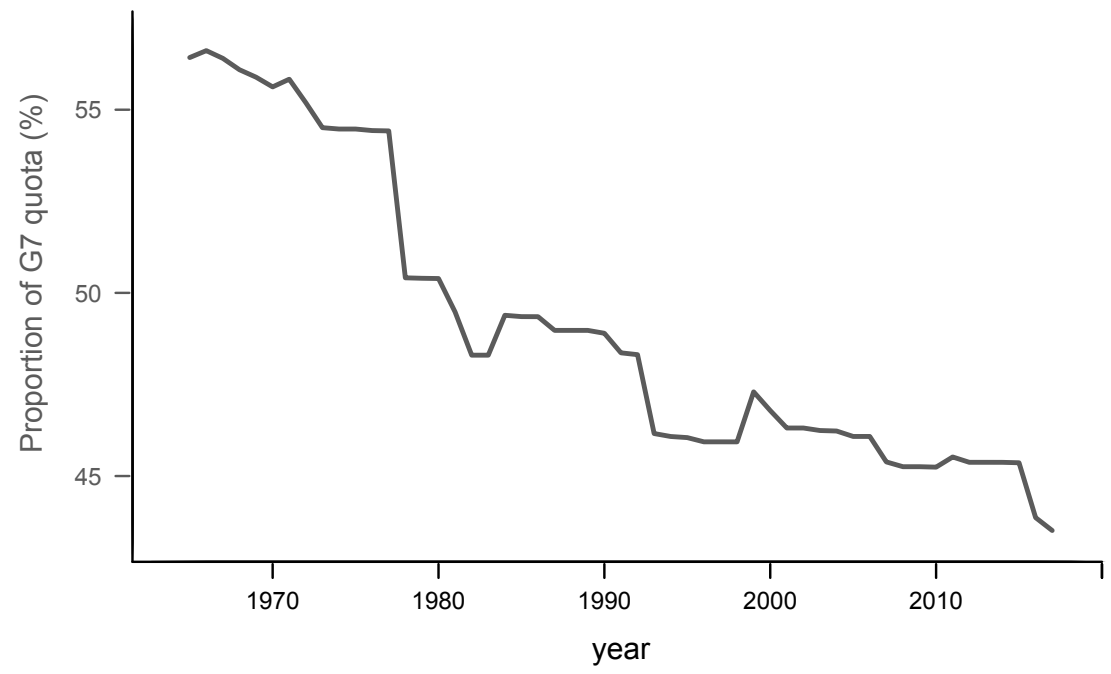

Figure E.1: Evolution of total IMF quota and G7 relative position

Notes: Data was hand collected from IMF Annual Reports. As we notice, until the beginning of the 1980s the Group of Seven had more than half of the total quota, a proportional to its voting power share.

\section{E.2 SBA and non-SBA}

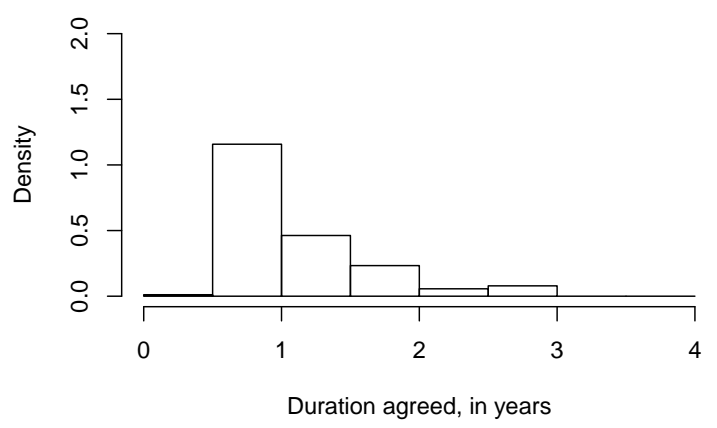

(a) SBA arrangements

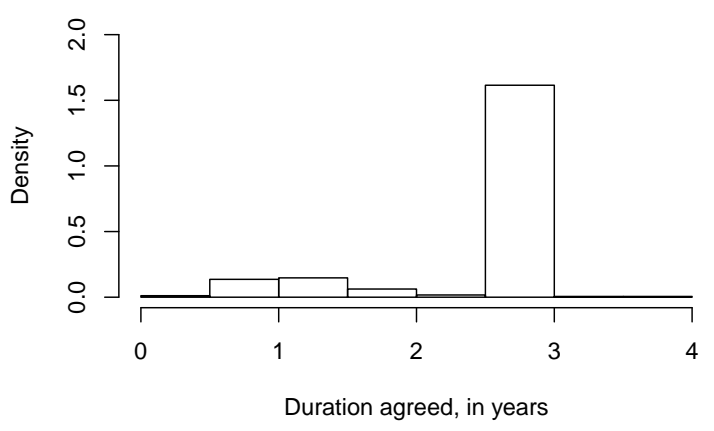

(b) Non-SBA arrangements

Figure E.2: Distributions of agreements duration, by type

Notes: Self-elaboration using a set that merges Kentikelenis et al. (2016) and data we collected from IMF Archives documents. 


\section{F Additional figures and tables for the heterogeneous effects section}

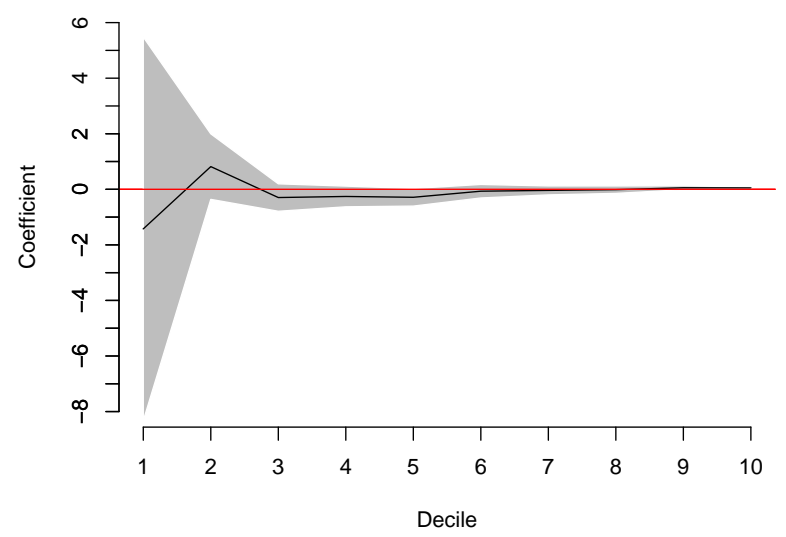

Figure F.1: Coefficient of the regression of conditionality against Distance to Communist and controls, on decile subsamples. Shaded area represents the $90 \%$ confidence level estimate. See table F.1 for full description of the exercise.

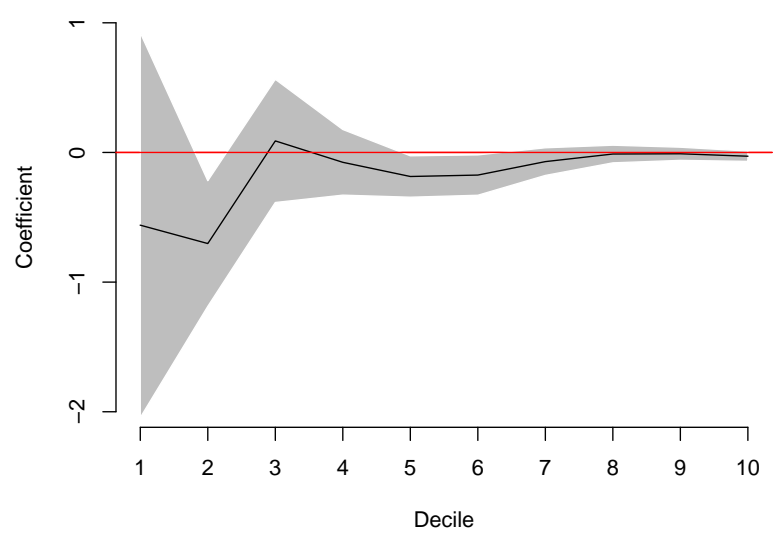

Figure F.2: Coefficient of the regression of conditionality against Distance to Communist WPC and controls, on decile subsamples. Shaded area represents the $90 \%$ confidence level estimate. See table F.3 for full description of the exercise. 
Dependent variable: $\log$ (Number of conditions)

\begin{tabular}{lcccccccccc} 
& $(1)$ & $(2)$ & $(3)$ & $(4)$ & $(5)$ & $(6)$ & $(7)$ & $(8)$ & $(9)$ & $(10)$ \\
\hline Distance to Communist & -1.424 & 0.817 & -0.296 & -0.258 & -0.288 & -0.068 & -0.039 & -0.013 & 0.056 & $0.050^{*}$ \\
& $(3.942)$ & $(0.733)$ & $(0.291)$ & $(0.207)$ & $(0.175)$ & $(0.138)$ & $(0.090)$ & $(0.073)$ & $(0.047)$ & $(0.026)$ \\
\hline Other controls & Yes & Yes & Yes & Yes & Yes & Yes & Yes & Yes & Yes & Yes \\
Observations & 22 & 41 & 65 & 85 & 105 & 126 & 147 & 165 & 186 & 207 \\
Adjusted R & -0.251 & 0.101 & 0.281 & 0.413 & 0.398 & 0.432 & 0.475 & 0.491 & 0.498 & 0.542 \\
\hline \hline
\end{tabular}

Table F.1: Determinants of number of conditions $(\log )$ : Buffer on deciles subsamples

Notes: Columns 1 to 10 represent the estimated coefficient for the correlation between the $\log$ of number of conditions and the distance to the closest communist countries, by deciles subsamples. Symbols ${ }^{*},{ }^{* *}$ and ${ }^{* * *}$ represent significance at 10,5 and 1 percent levels, respectively. White robust errors in brackets. Distances... measured in thousands of kilometres. Other controls: Alignment to the US at UNGA, exchange rate variation of local currency compared to US dollars, consumer prices variation, GDP growth, broad money growth, GDP per capita measured in thousands of 2010 US dollars, percentage of country's quota in total IMF quotas, proportions of imports from US, exports to US, temporary membership of the United Nations Security Council and a constant term. We include both post-1991 and Republican dummies in all regressions. We consider only SBA.

Dependent variable: $\log$ (Number of conditions)

\begin{tabular}{|c|c|c|c|c|c|c|c|c|c|c|}
\hline & (1) & (2) & (3) & (4) & (5) & (6) & (7) & (8) & (9) & (10) \\
\hline \multirow[t]{2}{*}{ Distance to Communist non-WPC } & $5.160^{*}$ & -0.423 & -0.174 & -0.009 & -0.069 & -0.041 & 0.004 & $0.076^{* *}$ & $0.070^{* * *}$ & $0.070^{* * *}$ \\
\hline & $(2.749)$ & $(0.579)$ & $(0.296)$ & $(0.183)$ & $(0.110)$ & $(0.094)$ & $(0.074)$ & $(0.032)$ & $(0.022)$ & $(0.019)$ \\
\hline Other controls & Yes & Yes & Yes & Yes & Yes & Yes & Yes & Yes & Yes & Yes \\
\hline Observations & 23 & 42 & 63 & 82 & 110 & 127 & 145 & 165 & 190 & 207 \\
\hline Adjusted $\mathrm{R}^{2}$ & 0.468 & 0.391 & 0.414 & 0.473 & 0.553 & 0.534 & 0.545 & 0.550 & 0.550 & 0.563 \\
\hline
\end{tabular}

Table F.2: Determinants of number of conditions (log): Buffer on deciles subsamples

Notes: Columns 1 to 10 represent the estimated coefficient for the correlation between the log of number of conditions and the distance to the closest non-aligned communist countries, by deciles subsamples. Symbols *,** and *** represent significance at 10, 5 and 1 percent levels, respectively. White robust errors in brackets. Distances... measured in thousands of kilometres. Other controls: Distance to closest communist non-WPC country, alignment to the US at UNGA, exchange rate variation of local currency compared to US dollars, consumer prices variation, GDP growth, broad money growth, GDP per capita measured in thousands of 2010 US dollars, percentage of country's quota in total IMF quotas, proportions of imports from US, exports to US, temporary membership of the United Nations Security Council and a constant term. We include both post-1991 and Republican dummies in all regressions. We consider only SBA. 
Dependent variable: $\log$ (Number of conditions)

\begin{tabular}{|c|c|c|c|c|c|c|c|c|c|c|}
\hline & (1) & (2) & (3) & (4) & (5) & (6) & (7) & (8) & (9) & (10) \\
\hline Distance to Communist WPC & $\begin{array}{l}-0.561 \\
(0.999)\end{array}$ & $\begin{array}{c}-0.703^{* *} \\
(0.338)\end{array}$ & $\begin{array}{c}0.089 \\
(0.227)\end{array}$ & $\begin{array}{l}-0.076 \\
(0.152)\end{array}$ & $\begin{array}{c}-0.185^{* *} \\
(0.091)\end{array}$ & $\begin{array}{c}-0.175^{* *} \\
(0.085)\end{array}$ & $\begin{array}{l}-0.071 \\
(0.064)\end{array}$ & $\begin{array}{l}-0.012 \\
(0.048)\end{array}$ & $\begin{array}{l}-0.010 \\
(0.037)\end{array}$ & $\begin{array}{l}-0.029 \\
(0.027)\end{array}$ \\
\hline Other controls & Yes & Yes & Yes & Yes & Yes & Yes & Yes & Yes & Yes & Yes \\
\hline Observations & 22 & 42 & 71 & 86 & 105 & 125 & 148 & 165 & 190 & 207 \\
\hline Adjusted $\mathrm{R}^{2}$ & 0.902 & 0.759 & 0.607 & 0.671 & 0.656 & 0.598 & 0.542 & 0.541 & 0.540 & 0.536 \\
\hline
\end{tabular}

Table F.3: Determinants of number of conditions $(\log )$ : Buffer on deciles subsamples

Notes: Columns 1 to 10 represent the estimated coefficient for the correlation between the log of number of conditions and the distance to the closest aligned Communist country, by deciles subsamples. Symbols *,** and *** represent significance at 10, 5 and 1 percent levels, respectively. White robust errors in brackets. Distances... measured in thousands of kilometres. Other controls: Distance to closest communist non-WPC country, alignment to the US at UNGA, exchange rate variation of local currency compared to US dollars, consumer prices variation, GDP growth, broad money growth, GDP per capita measured in thousands of 2010 US dollars, percentage of country's quota in total IMF quotas, proportions of imports from US, exports to US, temporary membership of the United Nations Security Council and a constant term. We include both post-1991 and Republican dummies in all regressions. We consider only SBA.

\section{G List of Communist “non-aligned” countries}

Here we list the countries that, for at least one year in our sample, were Communist states that did not serve as members of the Comecon and the Warsaw Pact.

Afghanistan (until 1979), Albania, Angola, Benin, China, People's Republic of the Congo, Ethiopia PDR (Derg), Grenada, Kampuchea, Lao PDR, Madagascar, Mozambique, DPR Korea, Somalia, Vietnam (until 1977), Yemen's People Republic and Yugoslavia. 